\title{
METALLOGENIC SETTING AND MATERIAL SOURCE OF CAIHONG COPPER-LEAD-ZINC POLYMETALLIC DEPOSIT IN XINJIANG, CHINA: EVIDENCES FROM A RESEARCH ON LITHOGEOCHEMISTRY, CHRONOLOGY AND STABLE ISOTOPE
}

\author{
CHEN, C. ${ }^{1}-$ WU, C. M. ${ }^{1 *}-$ LÜ, X. ${ }^{1,2}-$ SU, Y. Y. ${ }^{3}-$ Aishan, M. ${ }^{4}$ \\ ${ }^{1}$ Institute of Geological Survey, China University of Geosciences, Wuhan, China, 430074 \\ ${ }^{2}$ Faculty of Earth Resources, China University of Geosciences, Wuhan, China, 430074 \\ ${ }^{3}$ Zijin Mining Group Co., Ltd, Shanghang, China, 364200 \\ ${ }^{4}$ Faculty of Geology and Mining, Xinjiang University, Urumchi, China, 830046 \\ *Corresponding author \\ e-mail:Wu_cug@foxmail.com; phone:027-67883017; fax:027-67883661
}

(Received 24 $4^{\text {th }}$ Oct 2016; accepted $20^{\text {th }}$ Dec 2016)

\begin{abstract}
Caihong copper-lead-zinc polymetallic deposit is located in the east of the orogenic belt of South Tianshan in Xinjiang, of which ore types mainly include lamellar, stripped and veined, net-veined $\mathrm{Cu}-\mathrm{Pb}-\mathrm{Zn}$ ore. Two types of ore forms and the differences among mineral assemblages showed that the deposit had gone through multi-stage mineralization. Research results showed that Caihong deposit was the volcanic exhalation sedimentation type deposit in the early mineralization stage, with the age of volcanic eruption of $426 \pm 4.2 \mathrm{Ma}$. Mineralization was formed in the oceanic crust subduction island-arc rift setting in the Middle-Late Silurian. The higher $\delta^{34} \mathrm{~S}$ value in ore sulfide and unreached fractionation equilibrium indicated that the sulphur in this stage was derived from the continental marginal arc volcanic magma and the seawater sulfate in the late Early Paleozoic Era. The $\delta \mathrm{D}$ value and $\delta^{18} \mathrm{O}$ value in quartz, as well as the Eu positive anomaly of sulfide implied that the ore-forming fluids were derived from the mixing of the submarine hydrothermal solution and magmatic water. The deposit was the magmatic hydrothermal filling-metasomatic type deposit in the late mineralization stage, and the mineralization was closely related to the Zhongbao granite intrusion, formed in the collision-extension transformation stage of the plates in the Early Permian. The lower $\delta^{34} \mathrm{~S}$ value of veined ore sulfide indicated that sulphur in this stage was mainly deep-seated magmatic sulphur in the Early Permian. The $\delta \mathrm{D}$ value and $\delta^{18} \mathrm{O}$ value in ore quartz, as well as the Eu negative anomaly of the sulfide implied that ore-forming fluid was derived from the mixing of the magmatic water of granite body in the late mineralization stage and the atmospheric precipitation.
\end{abstract}

Keywords: South Tianshan, Caihong deposit, ore genesis, U-Pb dating, geochemistry

\section{Introduction}

Caihong copper-lead-zinc polymetallic deposit is located in the east of the orogenic belt of South Tianshan in Xinjiang,which includes lamellar $\mathrm{Zn}-\mathrm{Pb}-\mathrm{Cu}$ ore bed, as well as the much developed veined and net-veined filling-metasomatic $\mathrm{Cu}-\mathrm{Pb}-\mathrm{Zn}$ ore body. Xue et al. (2012) suggested that the deposit was volcanic eruption sedimentationvolcanic hydrothermal superimposed type deposit, of which deformation was caused by the early-stage volcanic hydrothermal. However, Su et al. (2011) believed that it was the volcanic sedimentation-magmatic hydrothermal superimposed deformation type deposit, and the superimposed mineralization was closely correlated with the magmatic activity in late plate collision. However, their samples were mainly veined ore, not containing 
lamellar ore samples. In order to understand the genesis of Caihong deposit better, there are two key problems need to be confirmed: tectonic-magmatic events and ore-forming material source in two mineralization stages. This paper discussed the above two problems through the geochemistry and volcanic eruption chronology of ore-bearing wall rock, and the rare earth elements, $\mathrm{H}-\mathrm{O}-\mathrm{S}$ isotope and fluid inclusion components of two types of ore, and based on the careful investigation for the geologic features of Caihong deposit, to provide evidences for the genesis of Caihong deposit.

\section{Geological setting}

The geotectonic position of ore district is located in the south margin of Central Tianshan block, bounded by Kumux basin on the south (Fig. 1). Previous research results showed that the oceanic crust of South Tianshan began the subduction to the northern Central Tianshan block in the Middle-Late Silurian Middle Devonian (Yang and Wang, 2006; Zhu et al., 2006; Zhang et al., 2007) which formed the huge thick island-arc volcanosedimentary rocks in the south margin of Kumux fault (Wu et al., 1992; Jiang et al., 1993; Shu et al., 2003). Lower Devonian Aerbishimaibulake formation was formed through the regional metamorphism of this rock series in the late period, mainly including various plagioclase schists, quartz-mica schist, calcareous schist, etc. The Mesoproterozoic Xingxingxia Group was widespread in the north of Kumux fault, which represented the crystalline basement of Central Tianshan block (Hu et al., 2006), while the basic and ultrabasic rocks in the south of Kumux basin represented the residue of ophiolite suite after the South Tianshan Ocean was closed (Dong et al., 2005; Yang et al., 2006). In addition, a few stratums in the Lower-Middle Silurian, Lower Carboniferous were exposed in this region. Kumux NWW-plunging anticline was the major structure in this region, which was basically parallel to the trending of the Kumishi fault. The intermediate-acid rock masses formed by the subduction and collision orogeny of plates were exposed in KumuxCaihuagou line in strip and were emplaced along the axial region and both wings of Kumux anticline (Chen et al., 2013).

\section{Deposit geology}

\section{Geologic background}

The stratums of Caihong ore district mainly include middle sub-formation $\left(\mathrm{D}_{1} \mathrm{a}^{\mathrm{b}}\right)$ and upper sub-formation $\left(\mathrm{D}_{1} \mathrm{a}^{\mathrm{c}}\right)$ of the Lower Devonian Aerbishimaibulake Formation (AF for short in Figure 2). Various quartz schists are formed in the stratums, which is affected by the regional metamorphism (Fig. 2a). Therein, the upper middle subformation $\left(\mathrm{D}_{1} \mathrm{a}^{\mathrm{b}-2}\right)$ is distributed in the middle of the mining area, mainly including sericite-quartz schist with sericite-biotite-quartz schist and marble, of which ore body is mainly occurred in the sericite-quartz alteration zone in this stratum. The fault within ore district mainly contains two groups: near east-west direction and north-east direction, while the latter has certain dislocation to alteration zone and ore body. The output of intrusive rocks in ore district is mainly in the form of dyke, which include diorite vein, granite-aplite vein and so on. There is no rock mass exposing in ore district, however, Zhongbao granite body is located two kilometers far away from the north of ore district, whose main lithology is two-mica monzogranite. Skarnization occurs in contact zone of granite and calcareous host rock and forms the skarn type tungsten deposit. 


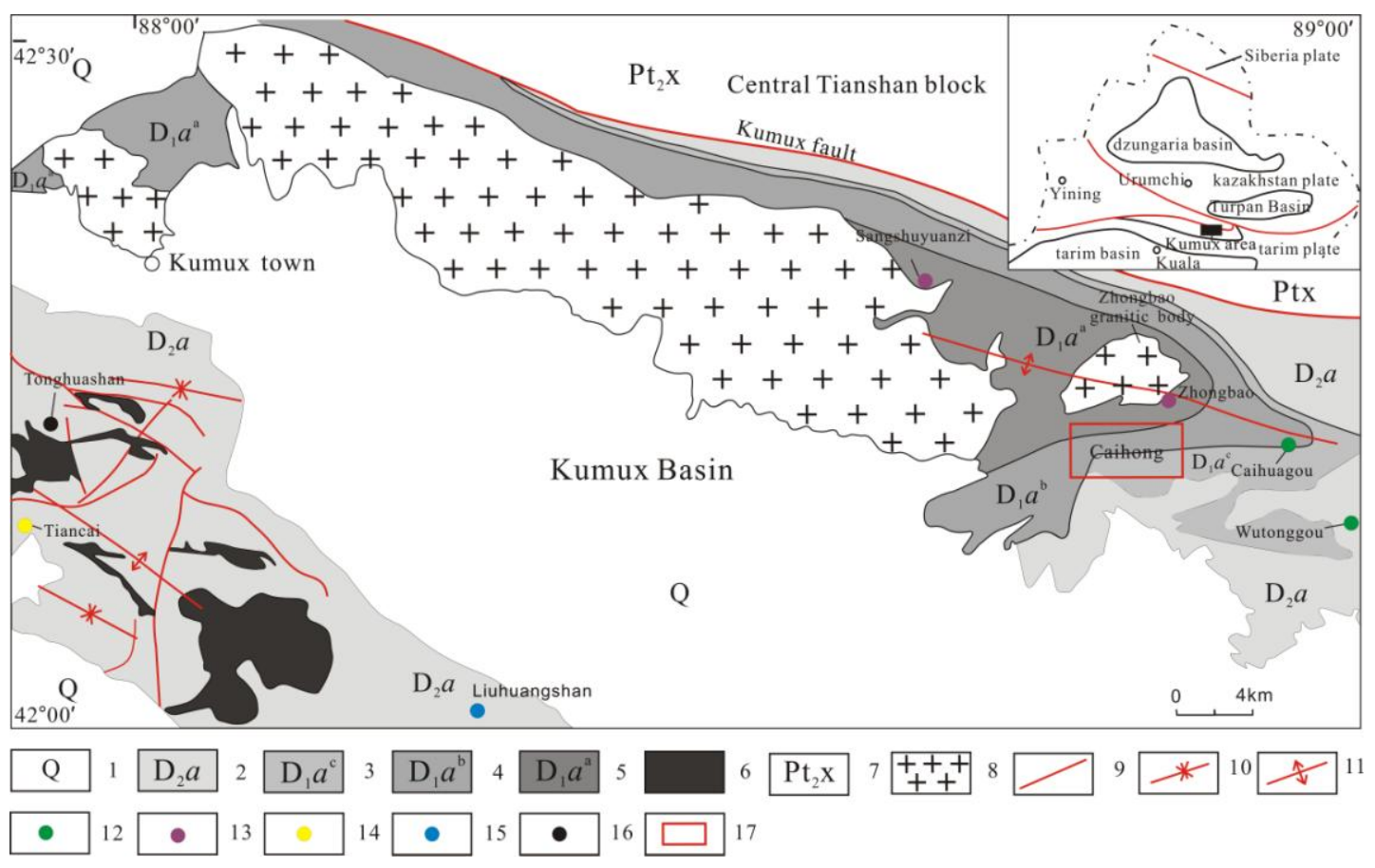

Figure 1. Regional geological map of Kumux area (modified from Su et al., 2011)

1. Quaternary; 2. Middle Devonian; 3. Upper sub-formation of Lower Devonian; 4. Middle subformation of Lower Devonian; 5. Lower sub-formation of Lower Devonian; 6. Basic-ultrabasic rock; 7. Mesoproterozoic Xingxingxia Gr; 8. granite; 9. Fault; 10. Syncline; 11. Anticline; 12. Copper-polymetalic deposite; 13. Tunsten deposite; 14. Gold deposite; 15. Lead-zinc deposite; 16. Cobalt-polymetalic deposite; 17. Caihong ore district

\section{Ore body characteristics}

Ore bodies of Caihong deposit are all hosted in sericite-quartz alteration zone of sub-formation $\left(\mathrm{D}_{1} \mathrm{a}^{\mathrm{b}}\right)$ in Aerbishimaibulake Formation. There are seven roughly parallel ore-bearing alteration zones within ore district and their shapes are mainly stratiform, quasi-lamellar and lens-like. The discontinuous phenomenon appeared along the trending of the alteration zone due to approximate east-west direction shear zone and the late period of north-east trending fault, forming the diagonal arrangement from north-east to west-south.

Number III alteration zone (Fig. 2a) is a main alteration zone in the ore district and five ore bodies are circled in the alteration zone. A-A', B-B' exploratory line profile shows the vertical characteristic of ore body (Figs. $2 b$ and $c$ ). Ore bodies are mainly copper ore and lead-zinc ore. The copper ore bodies are generated in lamellar and lentoid forms. Influenced by deformation, lentoid multilayer ore body may be a "pseudomorph" after primary lamellar ore body is transformed. Veined copper ore bodies are mostly filled along the late fault and some of which cross the lamellar ore body. Lead-zinc ore bodies are generated together with copper ore body and generated mainly in lenticle form. Disseminated and net-veined lead-zinc mineralization can be seen which is mostly filled along the late fault. Exploratory line profile shows that leadzinc and copper ore body of in the ore district not only have separation in the space, but also have definite overlap, which implies that the deposite may have multi-period mineralization. 


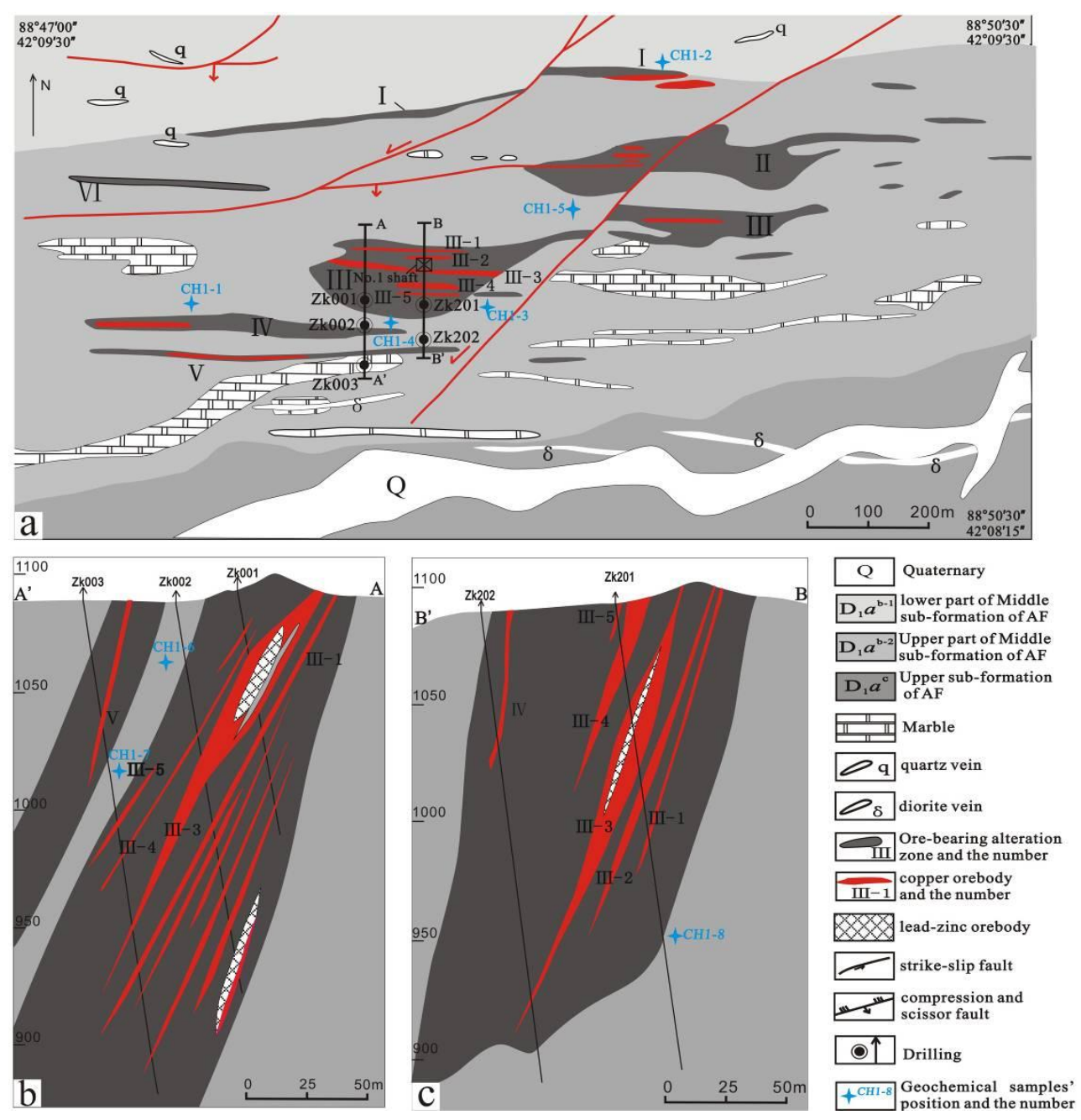

Figure 2. Geological map and ore body profile map of Caihong ore district (a is modified from Su et al., 2011; $b$ and c are modified from the exploration report of Caihong deposite, unpublished)

\section{Ore characteristics}

Primary ores can be divided into two types according to form and mineral assemblage. One type of ores is bedded and stripped with sedimentary characteristics. This type of ores can be further divided into two subtypes, therein one subtype is cupriferous pyrite ores including chalcopyrite and pyrite (Fig. 3a). The chalcopyrite is embedded in self-type and half-self-type pyrite crystal gap (Fig. 4a). Another subtype is $\mathrm{Zn}-\mathrm{Pb}-\mathrm{Cu}$ type ore (Fig. $3 b$ ), and most sphalerites are embedded in self-type and halfself-type pyrite crystal gap, replacing the dissolving pyrite (Fig. 4b). Galena replaces or packages sphalerite with the latest formation time. The gradient transition appears between foregoing mineralization and host rock, and the synchronous fold with strata can be seen locally, which has obvious metallogenic characteristics of syndeposition (Fig. 3c).

The other main type concludes veined anddisseminated ores, mainly distributed in quartz veins filling along the late fault. According to the combination of minerals, it can be divided into: 1Copper ore: The main minerals combinations are chalcopyrite and 
pyrite (Figs. $3 d$ and g), disseminated and nodular structure lump like structure, metasomatic relict texture. 2Copper-lead-zinc ore: The main minerals combinations are chalcopyrite + sphalerite + pyrite + galena (Figs. $3 e$ and $h$ ), as well as a small number of chalcocite, pyrrhotite, arsenopyrite (Fig. 4d), disseminated and massive structure, fault filling structure, metasomatic relict texture (Figs. $4 c$ and $g$ ). (3Lead-zinc ore: The main minerals are sphalerite and galena, as well as chalcopyrite, pyrite and bornite, etc. (Figs. $3 f$ and $i$ ), disseminated structure, fissure filling structure, metasomatic relict texture (Figs. $4 e$ and $f$ ). In addition, a small amount of sulfide production was also seen in the late calcite veins(Figs. $4 h$ and $i)$.
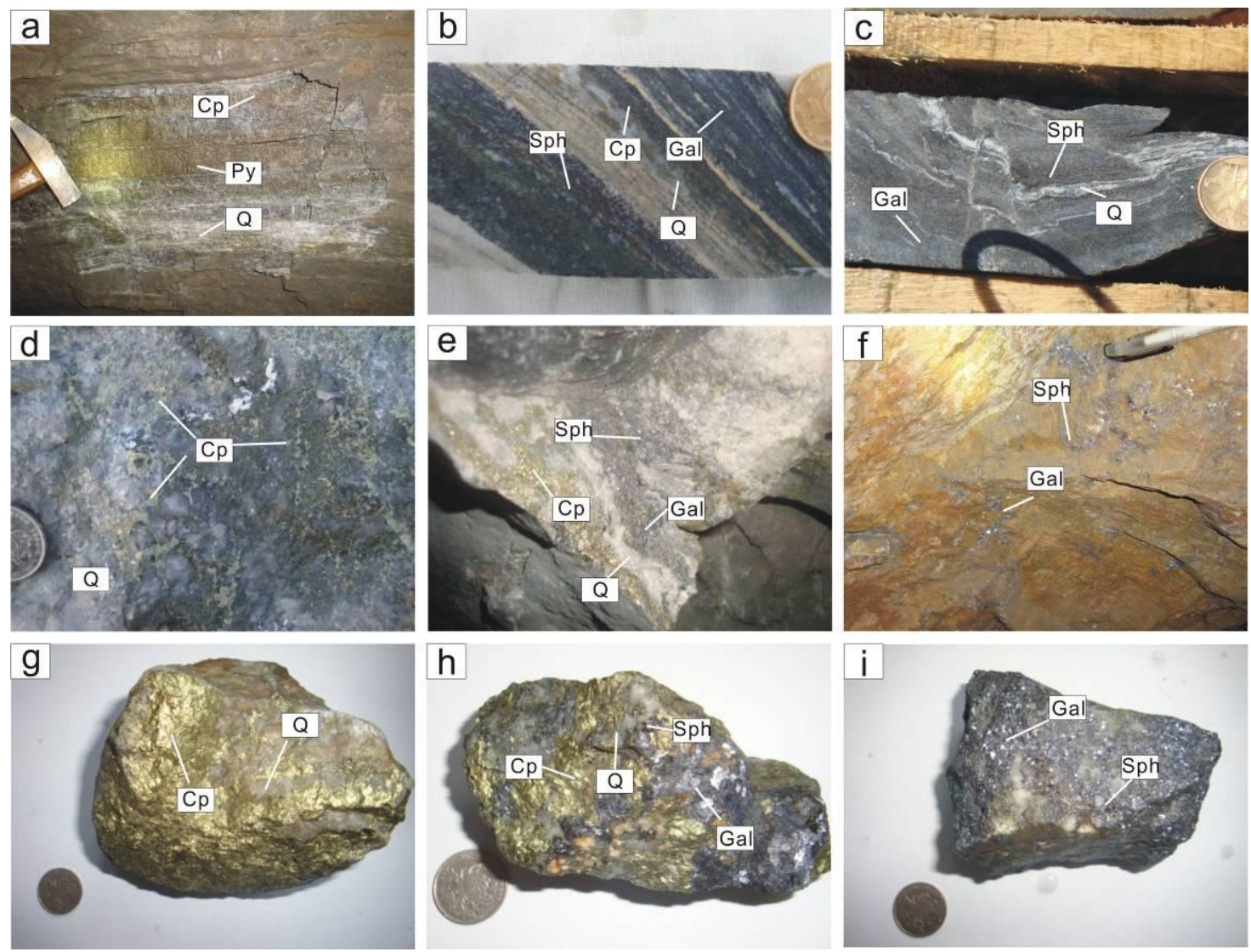

Figure 3. Ore types and formations of Caihong ore district

a. Lamellar chalcopyrite $(C p)+$ pyrite $(P y)$ ore; $\quad b$. Lamellar galena $(G a l)+$ sphalerite $(S p h)$ + chalcopyrite $(C p)$ ore; $c$. Lamellar sphalerite $(S p h)+$ galena $(G a l)$ ore fold deformation; $d$. Disseminated chalcopyrite $(C p)$ ore; e. Veined chalcopyrite $(C p)+$ galena $(G a l)+$ sphalerite $(S p h)$ ore; $f$. Disseminated galena $(\mathrm{Gal})+$ sphalerite $(\mathrm{Sph})$ mineralization; g. Massive chalcopyrite $(\mathrm{Cp})$ ore; $h$. Dense disseminated chalcopyrite $(\mathrm{Cp})+$ galena $(\mathrm{Gal})+$ sphalerite $(\mathrm{Sph})$ ore; $i$. Disseminated galena $(\mathrm{Gal})+$ sphalerite $(\mathrm{Sph})$ ore

\section{Transformation of ore body}

Field observation showed that the following factors controlled the occurrence of the ore body. 


\section{Regional metamorphism}

As affected by the regional metamorphism, the mining stratum generally generated the regional structural foliation $\left(S_{1}\right)$. There was a dip angle of $30 \sim 50^{\circ}$ between the primary bedding surface $\left(\mathrm{S}_{0}\right)$ and $\mathrm{S}_{1}$ (Fig. $5 a$ ). Obviously, such process might cause the fold deformation of syngenetic sedimentary ore-bearing bed.
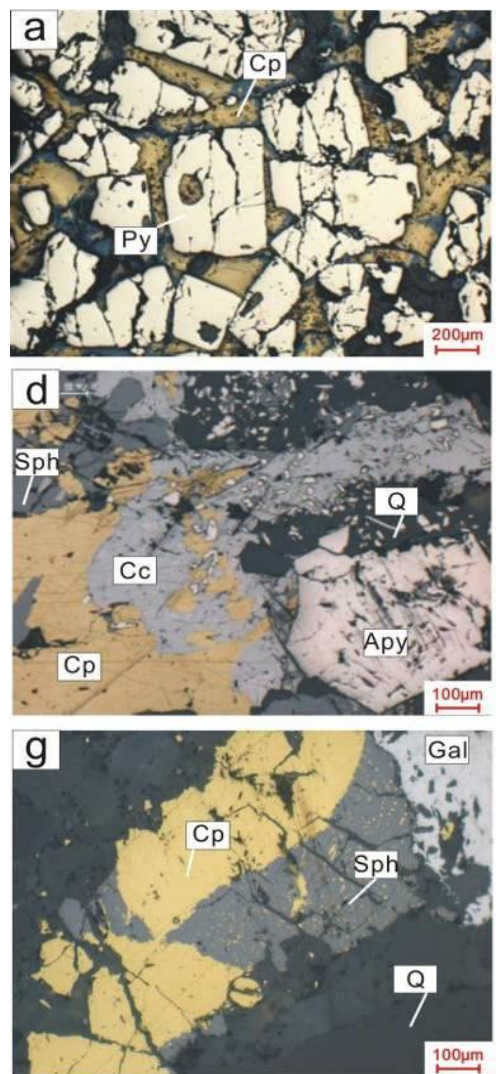
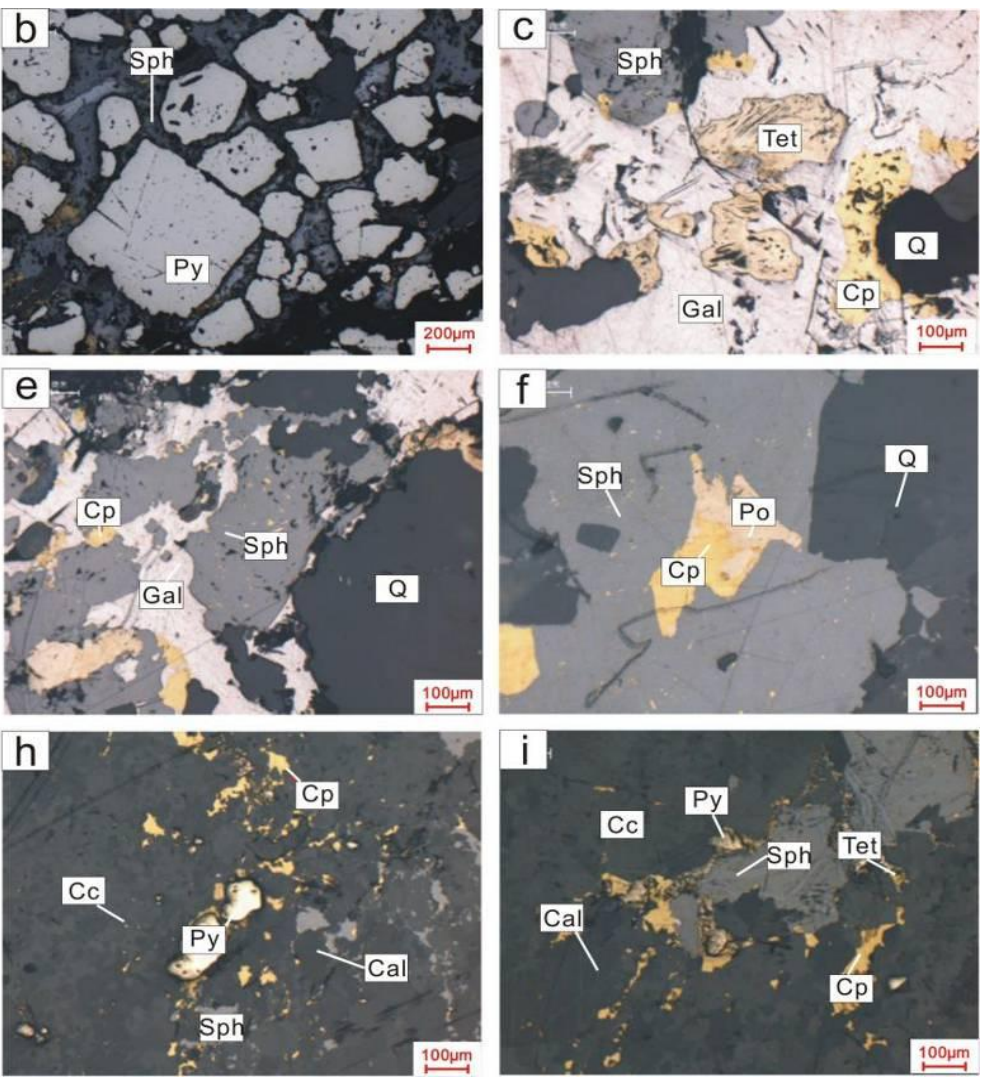
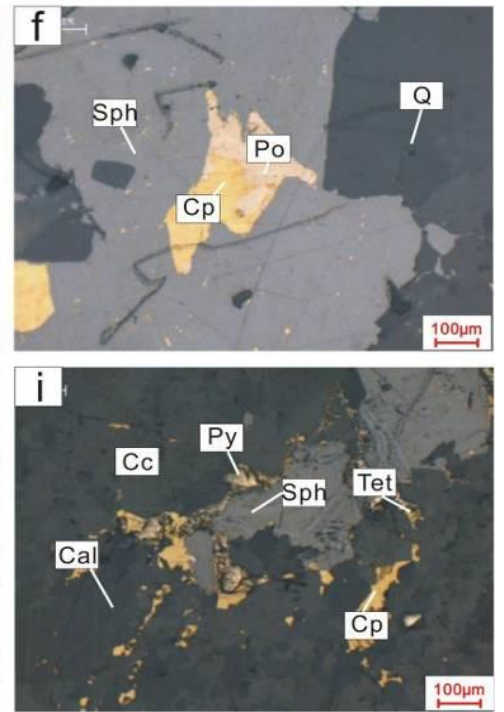

Figure 4. Ore structure of Caihong ore district

a. Chalcopyrite $(\mathrm{CP})$ in the lamellar ore are filled in earlier pyrite (Py) formed by self; $b$. Sphalerites (Sph) in the lamellar ore are filled in earlier pyrite (Py) formed by self; $c$. Metasomatic palimpsest texture, galena $(\mathrm{Gal})+$ sphalerite $(\mathrm{Sph})+$ chalcopyrite $(\mathrm{Cp})$ + tetrahedrite (Tet); $d$. Veined inter-penetration texture, sphalerite $(S p h)+$ chalcopyrite $(C p)+$ chalcocite $(C c)+$ arsenopyrite (Apy); e. Metasomatic palimpsest texture, sphalerite $(\mathrm{Sph})+$ galena $(\mathrm{Gal})+$ chalcopyrite $(\mathrm{Cp}) ; f$. Emulsion texture, sphalerite $(\mathrm{Sph})+$ chalcopyrite $(\mathrm{Cp})+$ pyrrhotite (Po); g. Metasomatic filling texture, galena $(\mathrm{Gal})+$ sphalerite $(\mathrm{Sph})+$ chalcopyrite $(C p) ;$. Pyrite $(P y)+$ chalcopyrite $(C p)+$ sphalerite $(S p h)+$ chalcocite $(C c)$ in calcite vein; $i$. Sphalerite $(\mathrm{Sph})+$ pyrite $(P y)+$ tetrahedrite $($ Tet $)+$ chalcocite $(\mathrm{Cc})+$ tetrahedrite $($ Tet $)$ in calcite vein

\section{Ductile shearing}

Some characteristic deformation structures in the ore district indicated the ductile shearing deformation in the late period, which also influenced the ore body shape. For instance: The thin marble and quartz vein were sheared and crumpled, eventually evolved to the rootless folding and lenticular body (Figs. $5 b$ and c), which caused a false impression of "multilayer" of part stratum and ore-bearing bed (Figs. $5 d$ and e). The regional flow cleavage and later fault cleavage were seen in the outcrop in the 
deposit (Fig. 5f), which reflected the structural configurations in different stress directions. In some pyrite-sphalerite-ore, the pyrite produced the brittle deformation, which had produced round and subangular grains, and such grains were distributed in the sphalerite regularly arranged in the elongated shape due to plastic deformation, which formed the sulfide stripe (Fig. $5 g$ ).
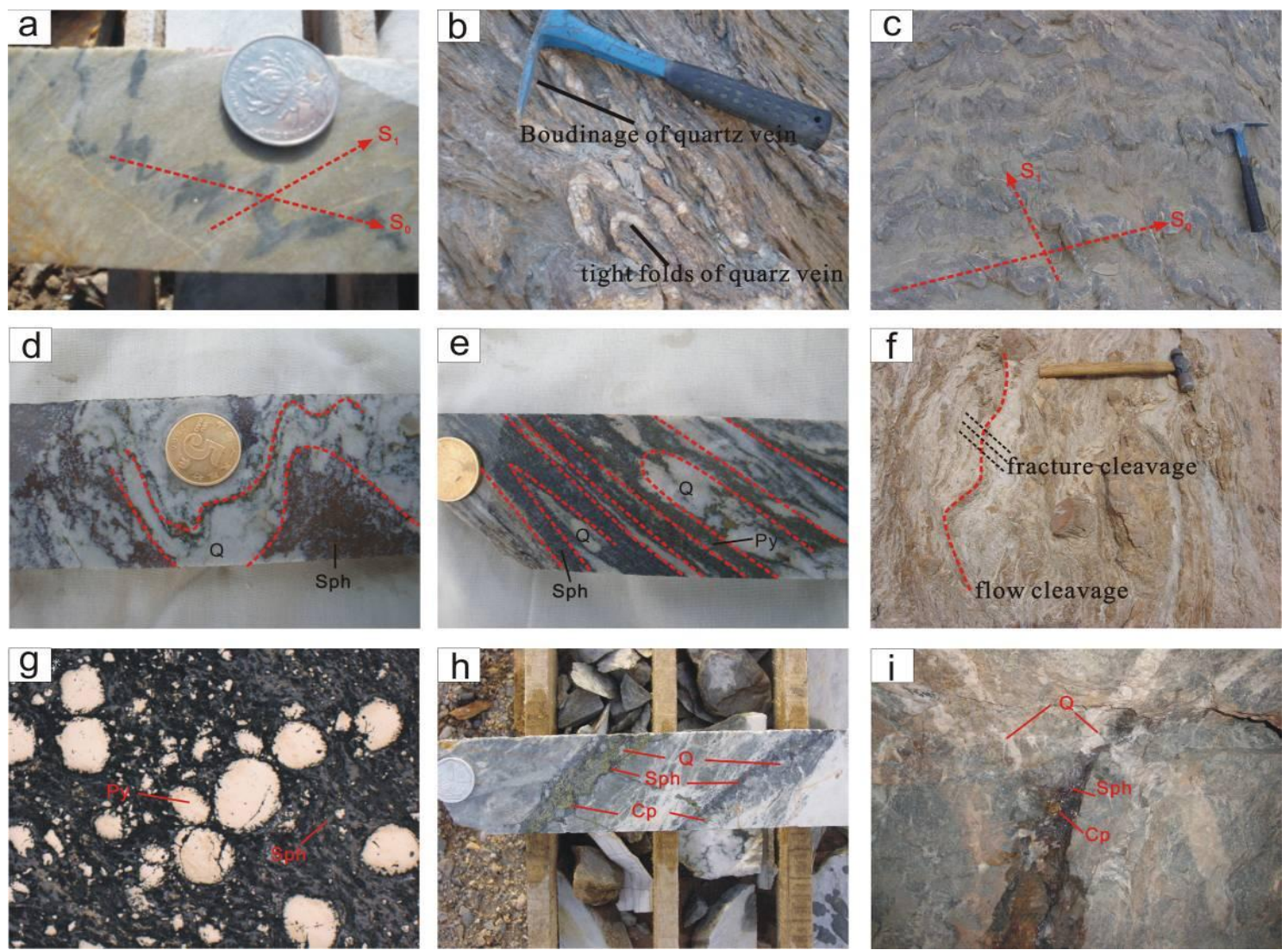

Figure 5. Characteristics of structure activities in Caihong ore district

a. Angle between primary stratification $\left(S_{0}\right)$ and structural foliation $\left(S_{1}\right) ; b$. Quartz tight fold and boudinage in stratum; c. Firstly fold and then shear of thin marble; $d$. Sphalerite(Sph) layer fold and local thickening; e. Multilayer illusion of sphalerite (Sph); f. flow cleavage and fault cleavage in stratum; g. Rounded pyrite(Py) distributed in plastically deforming sphalerite(Sph); $h$. chalcopyrite $(C p)$ and sphalerite $(S p h)$ in the brittle fault; $i$. chalcopyrite $(C p)$ and sphalerite(Sph) in the intersection part of several faults.

\section{Brittle fault}

Ore district exist fragmentized fault with obvious brittle deformation characteristic, which was filled with veined ore and forms quartz-calcite-sulfide vein. Such vein was not subject to deformation or metamorphism (Fig. 5h), suggesting that the vein was formed later than regional metamorphism and ductile shear effect. The silicification and mineralization intensities increased in the intersection part of fault structure (Fig. 5i), which indicated that ore-forming hydrothermal solution in the later period played an important role in further accumulation of metallogenic materials. 


\section{Sample descriptions and analytical methods}

\section{Major and trace elements analyses}

Samples selected from the ore-bearing host rock in Aerbishimaibulake Formation $\left(D_{1} a^{b}\right)$ and the lamellar and the veined ore sulfide were analyzed with sample description shown in Tables 1 and 2. Major elements were analyzed with a PAN analytical Axios X-ray fluorescence spectrometer (XRF) at ALS Chemex(Guangzhou) Co Ltd. A calcined or ignited sample $(0.9 \mathrm{~g})$ is added to $9.0 \mathrm{~g}$ of Lithium Borate Flux $\left(50 \%-50 \% \mathrm{Li}_{2} \mathrm{~B}_{4} \mathrm{O}_{7}-\mathrm{LiBO}_{2}\right)$, mixed well and fused in an auto fluxer between 1050$1100^{\circ} \mathrm{C}$. A flat molten glass disc is prepared from the resulting melt. This disc is then analyzed by X-ray fluorescence spectrometry. The precision of the XRF analyses at ALS Chemex is better than 5\%.Trace element concentrations were determined with an Elan 9000 at the same lab. A prepared sample $(0.2 \mathrm{~g})$ is added to lithium metaborate flux $(0.9 \mathrm{~g})$, mixed well and fused in a furnace at $1000{ }^{\circ} \mathrm{C}$. The resulting melt is then cooled and dissolved in $100 \mathrm{ml}$ of $4 \% \mathrm{HNO} 3 / 2 \% \mathrm{HCl} 3$ solution. This solution is then analyzed by inductively coupled plasma-mass spectrometry (ICP-MS). The precision of the ICPMS analyses at ALS Chemex is better than $10 \%$ for all elements.

\section{Zircon U-Pb chronology}

Zircon were selected from the ore-bearing sericite quartz schist of Aerbishimaibulake Formation $\left(\mathrm{D}_{1} \mathrm{a}^{\mathrm{b}}\right)(\mathrm{CH} 1-4, \mathrm{CH} 1-6)$. U-Pb Dating was finished in State Key Laboratory of Geological Processes and Mineral Resource, China University of Geosciences (Wuhan). The content analyses of U-Pb isotope and trace elements were conducted by using GeoLas2005 Excimer Laser ablation system and Agilent 7500a ICP-MS, with laser ablation beam spot diameter of $32 \mu \mathrm{m}$; for zircon ages, zircon 91500 was selected as the external standard sample and GJ-1 was selected as the internal standard sample. For elements contents, SRM610 was selected as the external standard sample and ${ }^{29} \mathrm{Si}$ was selected as the internal standard element. The detailed operation process and data can be seen from Liu et al. $(2008,2010)$.

\section{Stable isotopes analyses}

\section{Sulfur isotope}

The sulfur isotope analysis was conducted for pyrite, chalcopyrite, galena and sphalerite. Sample descriptions and position are shown in Table 4. The test was completed in State Key Laboratory of Geological Processes and Mineral Resource, China University of Geosciences (Wuhan). All sulfide monominerals and cuprous oxide were heated under vacuum environment and to be oxidized into sulfur dioxide. The sulfur isotope composition of the collected $\mathrm{SO}_{2}$ was analyzed by using MAT-251 isotope mass spectrometer that made in Germany. The accuracy could be indirectly given by the analysis results of certified reference material and the error was $\pm 0.2 \%$.

\section{Hydrogen and oxygen isotope}

Sample descriptions of mineralization-period quartz are shown in Table 5. The test was finished in isotope laboratory of Institute of Mineral Resources, Chinese Academy of Geological Sciences. The samples were reacted with pure $\mathrm{BrF}_{5}$ under the constant temperature of $550 \sim 700^{\circ} \mathrm{C}$ and then $\mathrm{O}_{2}$ was obtained. The purified $\mathrm{O}_{2}$ was reacted with 
carbon rod under the catalysis of $700^{\circ} \mathrm{C}$ platinum and the $\mathrm{CO}_{2}$ were collected to accept mass spectrometric measurement. The inclusion was open with thermal explosion process and the water was gained. The gained water was reacted with $\mathrm{Zn}$ and then hydrogen available for mass spectrometric measurement was gained. The oxygen isotope composition of quartz and the hydrogen isotope composition of fluid inclusion were treated with MAT252 mass spectrometric measurement. The analysis error for $\delta \mathrm{D}_{\mathrm{SMOW}}$ and $\delta^{18} \mathrm{O}_{\mathrm{H} 2 \mathrm{O}}$ were $2 \%$ and $0.2 \%$, respectively.

\section{Results}

\section{Major and trace elements}

The analysis results of major and trace elements in ore-bearing host rock is shown in Table 1. $\mathrm{SiO}_{2}$ content is in the range of $61.65-73.44 \mathrm{wt} . \%$ and the $\mathrm{Al}_{2} \mathrm{O}_{3}$ content is within $8.42-14.41$ wt.\%. Fig. $6 a$ and Fig. $6 b$ are used to determine the original rock components of host rock, four samples are distributed in the region of volcanic rocks, while other four samples are located in sedimentary rocks (sandstones) region. There are partial samples located in the boundary between sedimentary rock and volcanic rock regions, which implies that original rocks have the transition characteristic of volcanic rocks-sedimentary rocks. Furthermore, Niggli value diagram (AF diagram) shows that the samples in sedimentary rock regions drop to quartz sandstone and greywacke regions (Fig. 6c), and $\mathrm{SiO}_{2}-\mathrm{Zr} / \mathrm{TiO}_{2}$ diagram shows that the samples in igneous rock region drop near andesites and rhyolites-dacites with the characteristic of neutral-acid volcanic rock components (Fig. $6 d$ ).
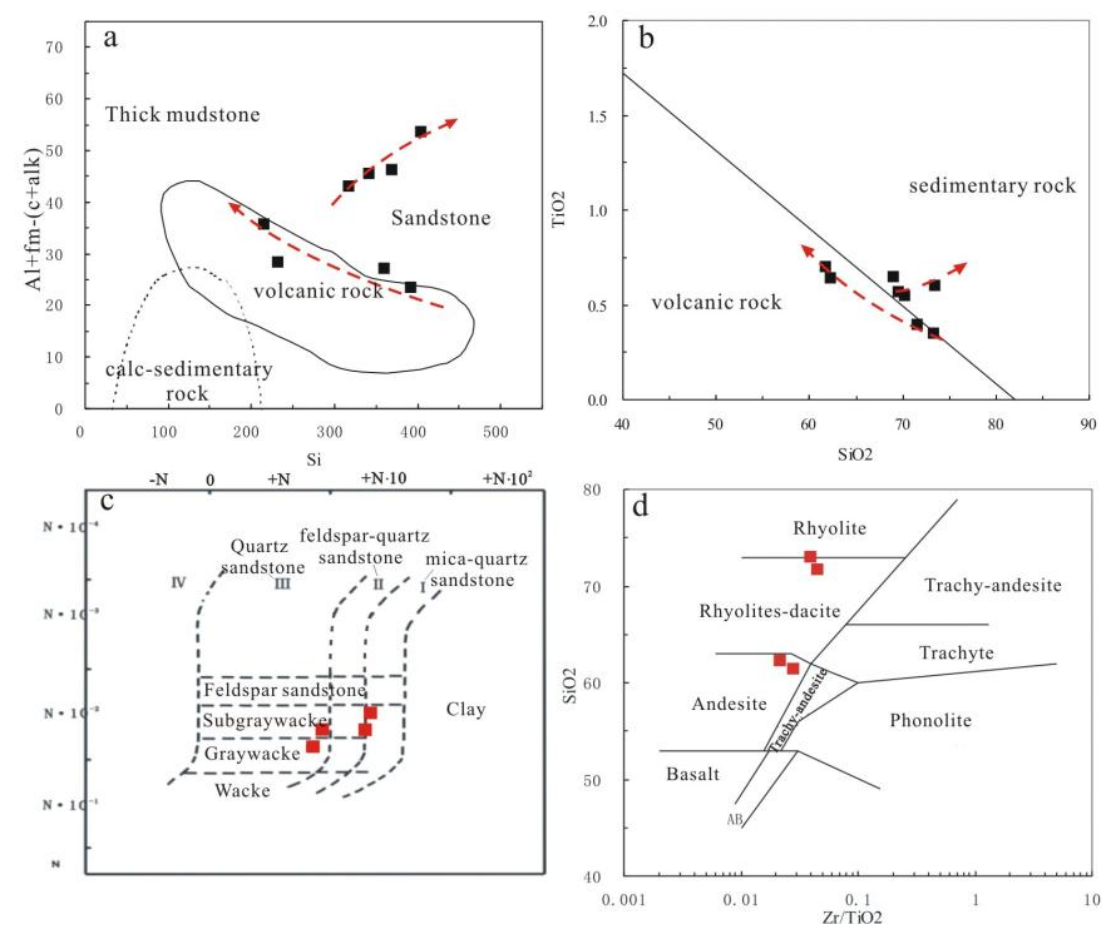

Figure 6. Diagram of metamorphic rock protolith restoration a. Al+fm-(c+alk)-Si diagram of protolith samples (Simonen, 1953); b. $\mathrm{TiO}_{2}-\mathrm{SiO}_{2}$ diagram of protolith samples (Tarney, 1976); c. AF diagram of sedimentary protolith samples (Wang et al., 1987); d. $\mathrm{SiO}_{2}-\mathrm{Zr} / \mathrm{TiO}_{2}$ diagram of igneous protolith samples (Winchester and Floyd, 1977) 
Table 1. Chemical compositions of ore-bearing host rock samples in Caihong deposite

\begin{tabular}{|c|c|c|c|c|c|c|c|c|}
\hline Sample number & CH1-1 & $\mathrm{CH} 1-2$ & CH1-3 & CH1-4 & CH1-5 & CH1-6 & CH1-7 & CH1-8 \\
\hline Sample lithology & $\begin{array}{c}\text { Biotite- } \\
\text { quartz } \\
\text { schist }\end{array}$ & $\begin{array}{c}\text { Sericite- } \\
\text { quartz } \\
\text { schist }\end{array}$ & $\begin{array}{c}\text { Biotite- } \\
\text { quartz } \\
\text { schist }\end{array}$ & $\begin{array}{c}\text { Sericite- } \\
\text { quartz } \\
\text { schist }\end{array}$ & $\begin{array}{c}\text { Biotite- } \\
\text { quartz } \\
\text { schist }\end{array}$ & $\begin{array}{c}\text { Sericite- } \\
\text { quartz } \\
\text { schist }\end{array}$ & $\begin{array}{c}\text { Biotite- } \\
\text { quartz } \\
\text { schist }\end{array}$ & $\begin{array}{c}\text { Sericite- } \\
\text { quartz } \\
\text { schist }\end{array}$ \\
\hline \multicolumn{9}{|c|}{ Major element (wt.\%) } \\
\hline $\mathrm{SiO}_{2}$ & 69.48 & 73.44 & 68.98 & 73.25 & 62.2 & 70.2 & 61.65 & 71.55 \\
\hline $\mathrm{TiO}_{2}$ & 0.57 & 0.6 & 0.65 & 0.42 & 0.64 & 0.45 & 0.7 & 0.5 \\
\hline $\mathrm{Al}_{2} \mathrm{O}_{3}$ & 11.56 & 12.05 & 14.41 & 8.42 & 13.02 & 9.25 & 13.5 & 10.09 \\
\hline $\mathrm{Fe}_{2} \mathrm{O}_{3}$ & 3.88 & 3.36 & 4.12 & 3.9 & 5.33 & 7.3 & 4.54 & 4.05 \\
\hline $\mathrm{FeO}$ & 3.14 & 2.16 & 1.82 & 1.96 & 4.27 & 1.58 & 3.45 & 2.57 \\
\hline $\mathrm{P}_{2} \mathrm{O}_{5}$ & 0.14 & 0.14 & 0.18 & 0.12 & 0.17 & 0.12 & 0.16 & 0.16 \\
\hline $\mathrm{CaO}$ & 3.03 & 0.66 & 0.69 & 4.15 & 5.26 & 1.56 & 5.65 & 2.66 \\
\hline $\mathrm{K}_{2} \mathrm{O}$ & 2.91 & 5.3 & 6.13 & 3.76 & 4.25 & 4.95 & 5.28 & 6.01 \\
\hline $\mathrm{MgO}$ & 2.22 & 1.68 & 1.08 & 1.28 & 2.88 & 1.1 & 1.81 & 1.22 \\
\hline $\mathrm{MnO}$ & 0.07 & 0.03 & 0.02 & 0.13 & 0.09 & 0.05 & 0.19 & 0.08 \\
\hline $\mathrm{Na}_{2} \mathrm{O}$ & 1.18 & 0.13 & 0.36 & 0.33 & 0.96 & 0.3 & 0.14 & 0.15 \\
\hline LOI & 1.87 & 1.16 & 1.62 & 1.76 & 1.57 & 2.32 & 2.82 & 1.87 \\
\hline Tatol & 99.85 & 99.91 & 100.06 & 99.48 & 99.84 & 99.18 & 99.89 & 99.92 \\
\hline \multicolumn{9}{|l|}{ Trace element (ppm) } \\
\hline $\mathrm{Ba}$ & 682 & 3842 & 1708 & 1910 & 1089 & 2460 & 808 & 871 \\
\hline $\mathrm{Ni}$ & 37.44 & 18.35 & 29.34 & 35.38 & 36.59 & 72.78 & 26.09 & 25.48 \\
\hline $\mathrm{Pb}$ & 11.96 & 7.08 & 53.08 & 615 & 44.31 & 782 & 42.16 & 15.14 \\
\hline $\mathrm{Cu}$ & 29.06 & 4108 & 226 & 3402 & 187 & 168 & 72.55 & 126 \\
\hline $\mathrm{Zn}$ & 131 & 156 & 168 & 4758 & 344 & 2612 & 78.34 & 31.25 \\
\hline $\mathrm{Ag}$ & 0 & 1.6 & 0.4 & 2.5 & 0.1 & 2.2 & 0.1 & 0.1 \\
\hline $\mathrm{U}$ & 2.71 & 1.95 & 2.81 & 1.83 & 2.54 & 2.06 & 2.41 & 2.35 \\
\hline $\mathrm{Th}$ & 9.93 & 10.25 & 9.72 & 6.42 & 11.3 & 7.24 & 9.61 & 10.46 \\
\hline $\mathrm{Co}$ & 11.75 & 8.71 & 13.02 & 13.06 & 14.12 & 18.98 & 8.62 & 11.41 \\
\hline $\mathrm{Ta}$ & 0.84 & 0.89 & 1.07 & 0.61 & 1.1 & 0.71 & 0.88 & 0.92 \\
\hline $\mathrm{Nb}$ & 10.42 & 10.78 & 11.87 & 7.11 & 15.64 & 8.08 & 11.41 & 10.82 \\
\hline Hf & 5.16 & 6.01 & 5.78 & 3.75 & 4.83 & 4.55 & 5.31 & 5.39 \\
\hline $\mathrm{Rb}$ & 115 & 143 & 228 & 103 & 179 & 126 & 202 & 156 \\
\hline $\mathrm{Zr}$ & 189 & 218 & 202 & 136 & 155 & 148 & 182 & 187 \\
\hline $\mathrm{Sr}$ & 101 & 50.44 & 58.55 & 96.93 & 129 & 91.14 & 139 & 115 \\
\hline $\mathrm{La}$ & 29.1 & 27.6 & 22.8 & 18 & 29.2 & 14.8 & 30.2 & 23.4 \\
\hline $\mathrm{Ce}$ & 56.6 & 52.5 & 48.8 & 36.3 & 58.3 & 34.2 & 56.7 & 55.6 \\
\hline $\operatorname{Pr}$ & 6.7 & 6.1 & 6 & 4.5 & 6.9 & 4.4 & 6.7 & 7.2 \\
\hline $\mathrm{Nd}$ & 25.6 & 21.3 & 24.2 & 18.6 & 26 & 17.8 & 26.7 & 29.5 \\
\hline $\mathrm{Sm}$ & 5 & 4.8 & 4.6 & 3.4 & 5.9 & 3.6 & 5.1 & 5.1 \\
\hline $\mathrm{Eu}$ & 1 & 0.62 & 0.8 & 0.51 & 1.2 & 0.52 & 1.2 & 0.57 \\
\hline $\mathrm{Gd}$ & 4.8 & 3.9 & 4.2 & 3.5 & 4.4 & 3.2 & 5.1 & 4.3 \\
\hline $\mathrm{Tb}$ & 0.69 & 0.71 & 0.6 & 0.56 & 0.77 & 0.5 & 0.76 & 0.68 \\
\hline Dy & 4 & 3.2 & 3.4 & 3.5 & 4.3 & 3 & 4.1 & 3.4 \\
\hline Ho & 0.74 & 0.63 & 0.68 & 0.65 & 0.92 & 0.58 & 0.82 & 0.59 \\
\hline $\mathrm{Er}$ & 2.1 & 1.5 & 1.8 & 1.9 & 2.3 & 1.6 & 2.4 & 1.7 \\
\hline $\mathrm{Tm}$ & 0.31 & 0.24 & 0.29 & 0.29 & 0.36 & 0.25 & 0.32 & 0.29 \\
\hline $\mathrm{Yb}$ & 1.9 & 1.7 & 1.9 & 2.1 & 2.5 & 1.7 & 2.2 & 1.9 \\
\hline $\mathrm{Lu}$ & 0.31 & 0.29 & 0.28 & 0.31 & 0.37 & 0.24 & 0.34 & 0.31 \\
\hline $\mathrm{Y}$ & 21.4 & 16.5 & 19.4 & 20.9 & 25.4 & 17.4 & 23.5 & 18.2 \\
\hline$\sum \mathrm{REE}$ & 138.85 & 125.09 & 120.35 & 94.12 & 143.42 & 86.39 & 142.64 & 134.54 \\
\hline LREE/HREE & 8.35 & 9.28 & 8.15 & 6.34 & 8.01 & 6.80 & 7.89 & 9.21 \\
\hline $\mathrm{La}_{\mathrm{N}} / \mathrm{Yb}_{\mathrm{N}}$ & 10.98 & 11.65 & 8.61 & 6.15 & 8.38 & 6.24 & 9.85 & 8.83 \\
\hline$\delta \mathrm{Eu}$ & 0.61 & 0.42 & 0.54 & 0.45 & 0.69 & 0.46 & 0.71 & 0.36 \\
\hline
\end{tabular}


Analysis results of REE in sulfide are listed in Table 2. The data shows that the LREE in veined ore sulfide is relative rich with Eu negative anomaly, where $\sum$ REE is 23.47 37.61, and $\delta \mathrm{Eu}$ is 0.43 0.73. For lamellar sulfide, LREE is relative rich with weak Eu positive anomaly. $\sum \mathrm{REE}$ is $3.56 \sim 5.43$, which is obviously lower than that the sulfide of veined ore, and $\delta \mathrm{Eu}$ is $0.55 \sim 2.50$. The differences among the rare earth element components of two types of ore sulfides imply that they probably have different sources.

Table 2. Rare earth element compositions of ore sulfide in Caihong deposite

\begin{tabular}{ccccccccc}
\hline Sample number & CH2-5 & CH2-6 & CH2-3 & CH2-2 & A3-F1 & A3-S1 & A1-3 & A4-1 \\
\hline \multirow{2}{*}{ Sample description } & $\begin{array}{c}\text { lamellar } \\
\text { galena }\end{array}$ & $\begin{array}{c}\text { lamellar } \\
\text { sphalerite }\end{array}$ & $\begin{array}{c}\text { lamellar } \\
\text { chalcopyrite }\end{array}$ & $\begin{array}{c}\text { lamellar } \\
\text { pyrite }\end{array}$ & $\begin{array}{c}\text { veined } \\
\text { galena }\end{array}$ & $\begin{array}{c}\text { vein } \\
\text { sphalerite }\end{array}$ & $\begin{array}{c}\text { vein } \\
\text { chalcopyrite }\end{array}$ & $\begin{array}{c}\text { vein } \\
\text { pyrite }\end{array}$ \\
\hline Trace element (ppm) & & & & & & & & \\
\hline $\mathrm{La}$ & 1.14 & 0.66 & 1.42 & 0.73 & 3.04 & 5.35 & 6.60 & 7.32 \\
$\mathrm{Ce}$ & 1.95 & 1.37 & 2.80 & 1.38 & 7.20 & 10.20 & 16.30 & 16.70 \\
$\mathrm{Pr}$ & 0.24 & 0.17 & 0.24 & 0.20 & 1.10 & 1.41 & 1.85 & 2.14 \\
$\mathrm{Nd}$ & 0.92 & 0.68 & 0.48 & 0.84 & 4.40 & 4.69 & 6.35 & 6.02 \\
$\mathrm{Sm}$ & 0.20 & 0.15 & 0.14 & 0.31 & 1.29 & 1.10 & 1.08 & 1.38 \\
$\mathrm{Eu}$ & 0.08 & 0.11 & 0.02 & 0.10 & 0.31 & 0.25 & 0.14 & 0.29 \\
$\mathrm{Gd}$ & 0.19 & 0.12 & 0.07 & 0.15 & 1.51 & 0.94 & 0.84 & 1.13 \\
$\mathrm{~Tb}$ & 0.03 & 0.02 & 0.01 & 0.03 & 0.28 & 0.16 & 0.12 & 0.18 \\
$\mathrm{Dy}$ & 0.24 & 0.11 & 0.09 & 0.08 & 1.63 & 0.80 & 0.63 & 0.93 \\
$\mathrm{Ho}$ & 0.04 & 0.02 & 0.02 & 0.03 & 0.37 & 0.17 & 0.13 & 0.20 \\
$\mathrm{Er}$ & 0.12 & 0.06 & 0.06 & 0.05 & 1.07 & 0.42 & 0.38 & 0.58 \\
$\mathrm{Tm}$ & 0.02 & 0.01 & 0.01 & 0.02 & 0.16 & 0.06 & 0.05 & 0.09 \\
$\mathrm{Yb}$ & 0.10 & 0.07 & 0.06 & 0.05 & 0.97 & 0.30 & 0.34 & 0.56 \\
$\mathrm{Lu}$ & 0.01 & 0.01 & 0.01 & 0.01 & 0.14 & 0.04 & 0.06 & 0.09 \\
\hline $\mathrm{KREE}$ & 5.27 & 3.56 & 5.43 & 3.98 & 23.47 & 25.89 & 34.87 & 37.61 \\
$\mathrm{LRE} / \mathrm{HREE}$ & 6.02 & 7.54 & 15.45 & 8.47 & 2.82 & 7.95 & 12.67 & 9.00 \\
$\mathrm{La} / \mathrm{Yb} \mathrm{N}_{\mathrm{N}}$ & 8.15 & 6.62 & 16.98 & 10.47 & 2.25 & 12.79 & 13.92 & 9.38 \\
$\delta \mathrm{Eu}$ & 1.31 & 2.50 & 0.55 & 1.25 & 0.68 & 0.73 & 0.43 & 0.69 \\
\hline
\end{tabular}

\section{Zircon $\mathrm{U}-\mathrm{Pb}$ age}

The zircons in host rock are long columnar, plate-shaped, transparent and pale brown, and inherited zircons can be seen in partial cores. Cathodoluminescence image shows that a majority of zircons have characteristic magmatic origin shock bands (Fig. 7). The obtained 25 groups of data results are listed in Table 3. The ratios of zircon $\mathrm{Th} / \mathrm{U}$ are between 0.41 and 1.16. HREE of zircons presents rich in chondrite-normalized diagram with obvious positive $\mathrm{Ce}$ anomaly and Eu negative anomaly (Fig. 8a). All above show the characteristics of magmatic zircons (Whitehouse, 2003; Cavosie et al., 2006). Four old ${ }^{206} \mathrm{~Pb} /{ }^{238} \mathrm{U}$ age values are near the crystallization ages of Late Archean and EarlyMiddle Mesoproterozoic Erathem of South Tianshan (Hu et al., 2006), which indicate that there are old crust basement components in magma. Two points with ${ }^{206} \mathrm{~Pb} /{ }^{238} \mathrm{U}$ concordia ages are not in the concordia, and it is likely caused by losing of $\mathrm{Pb}$. The concordance degree of remaining 19 points is better, ${ }^{206} \mathrm{~Pb} /{ }^{238} \mathrm{U}$ age range is between $404 \pm 7 \mathrm{Ma}$ and $452 \pm 8 \mathrm{Ma}$, weighted average age is 426.6 $\pm 4.2 \mathrm{Ma}(\mathrm{MSWD}=3.9)$ (Fig. 8b). With the characteristics of the zircons, it is believed that the obtained age shall represent the eruption age of volcanic original rock of ore-bearing wall rock. 
Table 3. Zircon U-Pb isotopic data of host rock in Caihong deposite

\begin{tabular}{|c|c|c|c|c|c|c|c|c|c|c|c|c|c|c|c|c|}
\hline \multirow{2}{*}{$\begin{array}{l}\text { Sample } \\
\text { number }\end{array}$} & \multirow{2}{*}{$\frac{\mathrm{Pb}(\text { Total })}{\mathrm{ppm}}$} & \multirow{2}{*}{$\begin{array}{l}\text { Th } \\
\text { ppm }\end{array}$} & \multirow{2}{*}{$\frac{\mathrm{U}}{\mathrm{ppm}}$} & \multirow{2}{*}{$-\mathrm{Th} / \mathrm{U}$} & \multicolumn{2}{|c|}{${ }^{207} \mathrm{~Pb} /{ }^{235} \mathrm{U}$} & \multicolumn{2}{|c|}{${ }^{206} \mathrm{~Pb} /{ }^{238} \mathrm{U}$} & \multicolumn{2}{|c|}{${ }^{208} \mathrm{~Pb} /{ }^{232} \mathrm{Th}$} & \multicolumn{2}{|l|}{${ }^{207} \mathrm{~Pb} /{ }^{235} \mathrm{U}$} & \multicolumn{2}{|l|}{${ }^{206} \mathrm{~Pb} /{ }^{238} \mathrm{U}$} & \multicolumn{2}{|l|}{${ }^{208} \mathrm{~Pb} /{ }^{232} \mathrm{Th}$} \\
\hline & & & & & Ratio & $1 \sigma$ & Ratio & $1 \sigma$ & Ratio & $1 \sigma$ & Age (Ma) & $1 \sigma$ & Age (Ma) & $1 \sigma$ & Age (Ma) & $1 \sigma$ \\
\hline CH-1 & 41.6 & 123 & 159 & 0.77 & 0.6333 & 0.0361 & 0.0709 & 0.0012 & 0.0211 & 0.0008 & 498 & 12 & 441 & 7 & 422 & 12 \\
\hline $\mathrm{CH}-2$ & 47.0 & 145 & 260 & 0.56 & 0.5029 & 0.0229 & 0.0658 & 0.0009 & 0.0198 & 0.0008 & 414 & 15 & 411 & 5 & 397 & 11 \\
\hline $\mathrm{CH}-3$ & 26.8 & 82.8 & 138 & 0.60 & 0.5957 & 0.0322 & 0.0647 & 0.0012 & 0.0214 & 0.0009 & 474 & 16 & 404 & 7 & 428 & 14 \\
\hline $\mathrm{CH}-4$ & 63.3 & 210 & 276 & 0.76 & 0.5622 & 0.0284 & 0.0672 & 0.0010 & 0.0207 & 0.0007 & 453 & 15 & 419 & 6 & 413 & 10 \\
\hline $\mathrm{CH}-5$ & 22.2 & 63.4 & 79.6 & 0.80 & 0.7185 & 0.0508 & 0.0684 & 0.0016 & 0.0215 & 0.0010 & 550 & 14 & 427 & 9 & 430 & 16 \\
\hline CH-6 & 25.1 & 72.9 & 149 & 0.49 & 0.5827 & 0.0342 & 0.0683 & 0.0011 & 0.0212 & 0.0010 & 466 & 16 & 426 & 7 & 424 & 8 \\
\hline $\mathrm{CH}-7$ & 23.1 & 54.9 & 108 & 0.51 & 0.6638 & 0.0393 & 0.0726 & 0.0014 & 0.0212 & 0.0010 & 517 & 18 & 452 & 8 & 424 & 9 \\
\hline $\mathrm{CH}-8$ & 41.2 & 129 & 174 & 0.74 & 0.5740 & 0.0287 & 0.0667 & 0.0012 & 0.0222 & 0.0008 & 461 & 16 & 416 & 7 & 444 & 11 \\
\hline $\mathrm{CH}-9$ & 50.0 & 138 & 243 & 0.57 & 0.5743 & 0.0300 & 0.0677 & 0.0010 & 0.0225 & 0.0009 & 461 & 17 & 422 & 6 & 449 & 13 \\
\hline $\mathrm{CH}-10$ & 36.3 & 113 & 180 & 0.63 & 0.5992 & 0.0299 & 0.0714 & 0.0011 & 0.0214 & 0.0009 & 477 & 19 & 445 & 7 & 427 & 14 \\
\hline $\mathrm{CH}-11$ & 19.1 & 101 & 87.5 & 1.16 & 0.8406 & 0.0568 & 0.0598 & 0.0013 & 0.0123 & 0.0007 & 619 & 19 & 374 & 8 & 248 & 10 \\
\hline $\mathrm{CH}-12$ & 119 & 69.8 & 96.7 & 0.72 & 6.6931 & 0.2118 & 0.3640 & 0.0046 & 0.1146 & 0.0039 & 2072 & 28 & 2001 & 22 & 2192 & 66 \\
\hline $\mathrm{CH}-13$ & 30.5 & 82.6 & 200 & 0.41 & 0.5591 & 0.0260 & 0.0723 & 0.0011 & 0.0217 & 0.0010 & 451 & 13 & 450 & 7 & 435 & 7 \\
\hline CH-14 & 190 & 107 & 64.1 & 1.67 & 10.4166 & 0.3029 & 0.4675 & 0.0064 & 0.1329 & 0.0036 & 2473 & 27 & 2473 & 28 & 2522 & 61 \\
\hline $\mathrm{CH}-15$ & 239 & 172 & 230 & 0.75 & 5.0088 & 0.1442 & 0.3305 & 0.0036 & 0.0904 & 0.0029 & 1821 & 24 & 1841 & 17 & 1749 & 50 \\
\hline CH-16 & 226 & 124 & 216 & 0.57 & 5.6031 & 0.1835 & 0.3365 & 0.0037 & 0.1189 & 0.0037 & 1917 & 28 & 1870 & 18 & 2271 & 63 \\
\hline $\mathrm{CH}-17$ & 39.6 & 123 & 203 & 0.60 & 0.5621 & 0.0317 & 0.0679 & 0.0011 & 0.0231 & 0.0010 & 453 & 12 & 424 & 7 & 461 & 15 \\
\hline CH-18 & 32.0 & 106 & 145 & 0.73 & 0.6142 & 0.0367 & 0.0703 & 0.0014 & 0.0219 & 0.0009 & 486 & 13 & 438 & 8 & 438 & 14 \\
\hline CH-19 & 38.0 & 111 & 171 & 0.65 & 0.5825 & 0.0312 & 0.0701 & 0.0011 & 0.0236 & 0.0009 & 466 & 9 & 437 & 7 & 471 & 14 \\
\hline $\mathrm{CH}-20$ & 52.7 & 158 & 198 & 0.80 & 0.6010 & 0.0325 & 0.0676 & 0.0012 & 0.0241 & 0.0009 & 478 & 14 & 422 & 7 & 482 & 15 \\
\hline $\mathrm{CH}-21$ & 80 & 274 & 254 & 1.08 & 1.0923 & 0.0565 & 0.0675 & 0.0013 & 0.0244 & 0.0012 & 750 & 13 & 421 & 8 & 486 & 15 \\
\hline $\mathrm{CH}-22$ & 51.8 & 154 & 255 & 0.61 & 0.5771 & 0.0272 & 0.0707 & 0.0010 & 0.0220 & 0.0008 & 463 & 15 & 441 & 6 & 441 & 12 \\
\hline $\mathrm{CH}-23$ & 22.2 & 65.6 & 106 & 0.62 & 0.5952 & 0.0340 & 0.0702 & 0.0013 & 0.0224 & 0.0010 & 474 & 14 & 437 & 8 & 448 & 11 \\
\hline $\mathrm{CH}-24$ & 66.6 & 217 & 277 & 0.78 & 0.5254 & 0.0229 & 0.0673 & 0.0009 & 0.0210 & 0.0007 & 429 & 15 & 420 & 6 & 421 & 10 \\
\hline $\mathrm{CH}-25$ & 72 & 250 & 298 & 0.84 & 0.4936 & 0.0242 & 0.0652 & 0.0010 & 0.0205 & 0.0007 & 407 & 12 & 407 & 6 & 409 & 9 \\
\hline
\end{tabular}




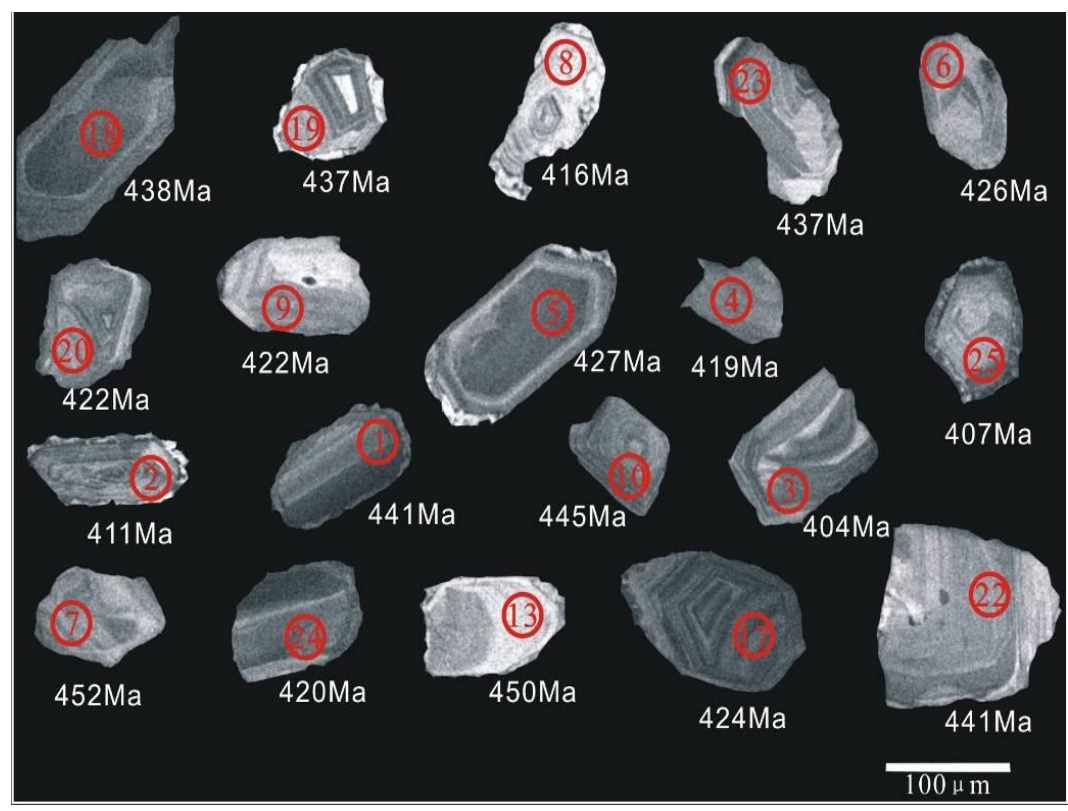

Figure 7. Cathodoluminescence (CL) image of host rock zircons
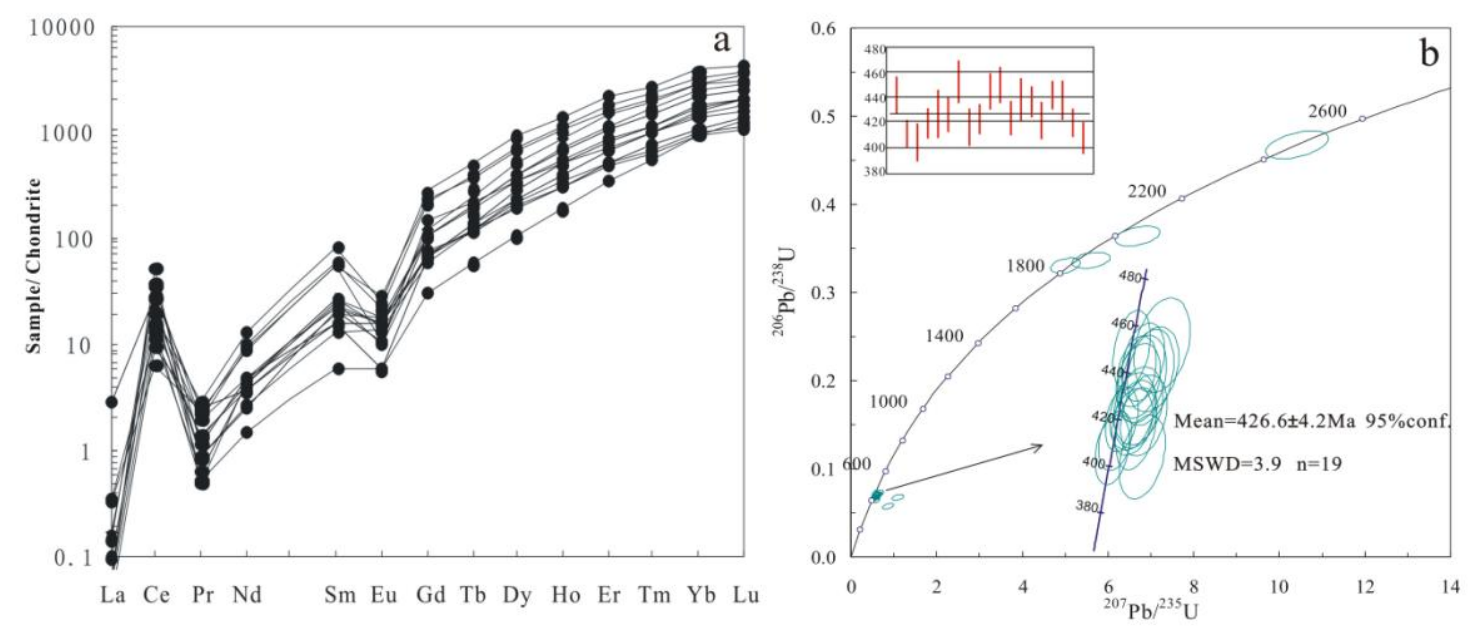

Figure 8. Chondrite-normalized REE patterns (a) and Concordance curve of zircon U-Pb Age(b)

\section{Sulfur isotope}

Descriptions and test results of sulfur isotope samples are presented in Table 4. In general, the $\delta^{34} \mathrm{~S}$ values of sulfur in early lamellar ore (average value is $5.31 \%$ ) are obviously higher than that of late veined ore (average value is 0.59\%o) ( $\mathrm{Su}$ et al., 2011), and $\delta^{34} \mathrm{~S}$ value shows the characteristic of bimodal distribution (Fig.9). The $\delta^{34} \mathrm{~S}$ values of two types of sulfurs do not completely conform to the $\delta^{34} \mathrm{~S}$ order of hydrothermal sulfide enrichment under fractionation equilibrium condition $\left(\delta^{34}\right.$ Spyrite $>\delta^{34} \mathrm{~S}_{\text {sphalerite }}>$ $\delta_{\text {Schalcopyrite }}^{34} \delta_{\text {Sgalena }}^{34}$ ) (Shan et al., 2009), implying that the sulfur may has nonuniform mixed source or influenced by multiple stages of mineralization (Zheng and Chen, 2000). 
Table 4. Sulfur isotopic composition of ore sulfides in Caihong deposite

\begin{tabular}{|c|c|c|c|}
\hline Sample number & Sample description & Position & $\delta 34 \mathrm{~S} \%$ \\
\hline A1-1 & net veined chalcopyrite & ZK201 & $0.8^{*}$ \\
\hline A1-2 & net veined chalcopyrite & ZK201 & $2.37 *$ \\
\hline A1-3 & veined chalcopyrite & ZK001 & $2.21^{*}$ \\
\hline A2-1 & veined chalcopyrite & $1050 \mathrm{~m}$ middle part of No.1 shaft & $1.34^{*}$ \\
\hline A3-1 & $\begin{array}{l}\text { disseminated } \\
\text { chalcopyrite }\end{array}$ & $1050 \mathrm{~m}$ middle part of No.1 shaft & $3.35^{*}$ \\
\hline A2-3 & $\begin{array}{l}\text { disseminated } \\
\text { chalcopyrite }\end{array}$ & $1000 \mathrm{~m}$ middle part of No.1 shaft & $1.85^{*}$ \\
\hline A3-F1 & veined galena & ZK001 & $0.13^{*}$ \\
\hline A3-F2 & net veined galena & ZK201 & $0.33^{*}$ \\
\hline A3-S1 & veined sphalerite & $1000 \mathrm{~m}$ middle part of No.1 shaft & $2.08^{*}$ \\
\hline A3-S2 & disseminated sphalerite & $1000 \mathrm{~m}$ middle part of No.1 shaft & $1.51^{*}$ \\
\hline A4-1 & veined Pyrite & ZK201 & $-4.37 *$ \\
\hline $\mathrm{A} 4-2$ & net veined Pyrite & ZK201 & $-1.92 *$ \\
\hline $\mathrm{CH} 2-2$ & lamellar Pyrite & ZK002 & 6.23 \\
\hline $\mathrm{CH} 2-3$ & lamellar chalcopyrite & ZK002 & 5.75 \\
\hline $\mathrm{CH} 2-4$ & banded chalcopyrite & ZK003 & 4.32 \\
\hline $\mathrm{CH} 2-5$ & banded galena & ZK003 & 5.63 \\
\hline $\mathrm{CH} 2-6$ & banded sphalerite & ZK003 & 5.14 \\
\hline $\mathrm{CH} 2-7$ & banded Pyrite & ZK003 & 6.75 \\
\hline
\end{tabular}

* veined and disseminated ore sulfer isotopic data is from Su et al. (2011).

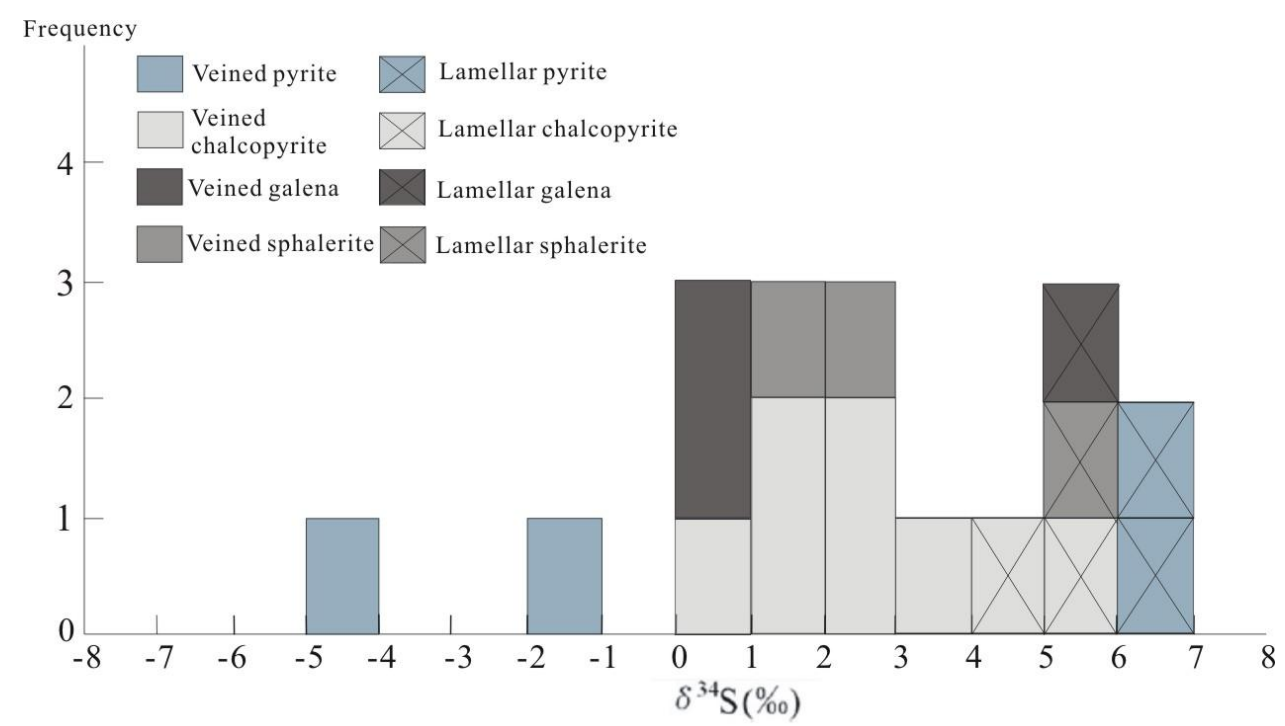

Figure 9. Frequency histogram of Sulfide isotopic content of ore sulfide

\section{Hydrogen and oxygen isotopes}

The test results of hydrogen and oxygen isotope in mineralizetion period quartz of lamellar sulfide ore are listed in Table 5. The oxygen isotope calibration is calculated and obtained by the conversion formula: ${ }^{18} \mathrm{O}_{\text {quartz }}{ }^{18} \mathrm{O}_{\text {water }}=3.306 \times 10^{6} \cdot \mathrm{T}^{-2}-2.71$ (Zhang 
et al., 1990). According to the genetic characteristics of early stage ore, it can be take the mean value of volcanic massive sulfide metallogenic temperature of $300^{\circ} \mathrm{Cfor}$ the quartz approximate metallogenic temperature in lamellar ore (Ohmoto, 1996). The $\mathrm{D}_{\mathrm{V}-}$ SMOw of lamellar ore quartz is between $-65 \%$ and-80\%, and ${ }^{18} \mathrm{O}_{\text {water value range is }}$ $3.21 \%-5.71 \%$ by formula. The $\delta \mathrm{D}_{\mathrm{SMOw}} \%$ and $\delta^{18} \mathrm{O}_{\mathrm{H} 2 \mathrm{O}} \%$ value of veined ore quartz are quoted from Su et al. (2011).

Table 5. Oxygen-hydrogen isotopic composition of ore quartz in Caihong deposite

\begin{tabular}{cccccc}
\hline Sample number & Sample description & Position & $\delta D_{\text {SMOw } \%}$ & $\delta^{18} \mathrm{O}_{\text {SMOw }} \%$ & $\delta^{18} \mathrm{O}_{\mathrm{H} 20 \%}$ \\
\hline CHT104-3 & veined ore quartz & ZK201 & $-94^{*}$ & 14.1 & $5.17^{*}$ \\
CH2-6 & veined ore quartz & ZK201 & $-82^{*}$ & 14.3 & $5.37^{*}$ \\
CHA5 & veined ore quartz & ZK201 & $-98^{*}$ & 14.2 & $5.27^{*}$ \\
CHA6 & veined ore quartz & ZK001 & $-119^{*}$ & 14.7 & $5.77^{*}$ \\
CHA7 & veined ore quartz & ZK001 & $-95^{*}$ & 14.1 & $5.12^{*}$ \\
CH3-1 & Lamellar ore quartz & ZK002 & -76 & 14.0 & 3.91 \\
CH3-2 & Lamellar ore quartz & ZK002 & -80 & 15.8 & 5.71 \\
CH3-3 & Lamellar ore quartz & ZK002 & -65 & 13.8 & 3.71 \\
CH3-4 & banded ore quartz & ZK003 & -66 & 13.3 & 3.21 \\
CH3-5 & banded ore quartz & ZK003 & -72 & 13.6 & 3.51 \\
\hline
\end{tabular}

* veined ore quartz hydrogen-oxygen isotopic data is from Su et al. (2011).

\section{Discussion}

\section{Metallogenetic tectonic setting}

With the lithologic characteristic of host rock and the results of lithochemistry protolith restoration of wall rock, it is inferred that felsic greywacke and andesiticdacite-rhyolite pyroclastic rock are main components of original rocks of ore-bearing wall rock. Greywacke components are closely relevant with plate tectonic setting. The contents of sandstones $\mathrm{TiO}_{2}, \mathrm{TFe}_{2} \mathrm{O}_{3}+\mathrm{MgO}$ and $\mathrm{Al}_{2} \mathrm{O}_{3} / \mathrm{SiO}_{2}$ decrease from oceanic island arc, continental island arc and active continental margin to passive continental margin (Bhatia, 1991). In Figure 10a and b, the samples of metasedimentary rock fall the host regions of continental island arc and active continental margin. Crook (1974) also pointed that the greywacke with medium content of quartz $\left(\mathrm{SiO}_{2}\right.$ content was between 68 wt.\% and wt.74\%) was generally formed in active continental margin island-arc or back-arc basin environment. In $\mathrm{Yb}-\mathrm{La} / \mathrm{Yb}$ and $\mathrm{Zr}-\mathrm{Hf}$ diagrams (Figs. 10c and $d$ ), all pyroclastic rock samples fall to arc volcanic rocks or volcanic basin region and they are rich in $\mathrm{K}, \mathrm{Rb}, \mathrm{Ba}$ and Th, and lack of HFSE of $\mathrm{P}, \mathrm{Ti}, \mathrm{Nb}$ and $\mathrm{Ta}$ (Fig.10e), as well as rich LREE with moderate or weak negative Eu anomaly (Fig. 10f), which indicate continental margin arc volcanic rock characteristics (Zhang et al., 2015).

In addition, lamellar marbles are distributed in host rock, and its original rocks obviously reflect the sedimentary characteristics of marginal sea basin. However, the marginal sea basins in island-arc environment include inter-arc basin and back-arc basin, but the sediments in inter-arc basins are generally pyroclastic rock without the injection of continental margin materials (Peng et al., 1999). It significantly does not be in consistence with the sandstone component of original rock. Furthermore, the ophiolite belt that represents remnant new oceanic crust are not found in northern margin of 
subduction zone, namely the island arc formed doesn't form new oceanic crust. Consequently, a reasonable explanation is that the island-arc environment is a kind of marginal sea basins formed in young back-arc environment with silicon aluminum continental crust base. The eruption age of pyroclastic rock original rock obtained in this paper is $426 \mathrm{Ma}$, which is mutually corroborated with the result that a series of continental marginal arc granite with ages between 436 and 396Ma were formed in northern Kumux and Central Tianshan regions(Zhu et al., 2006; Zhang et al., 2007; Yang et al., 2006; Long et al., 2007), both of which indicated the existence of continental marginal magmatic arc from the Middle-Late Silurian in this region.
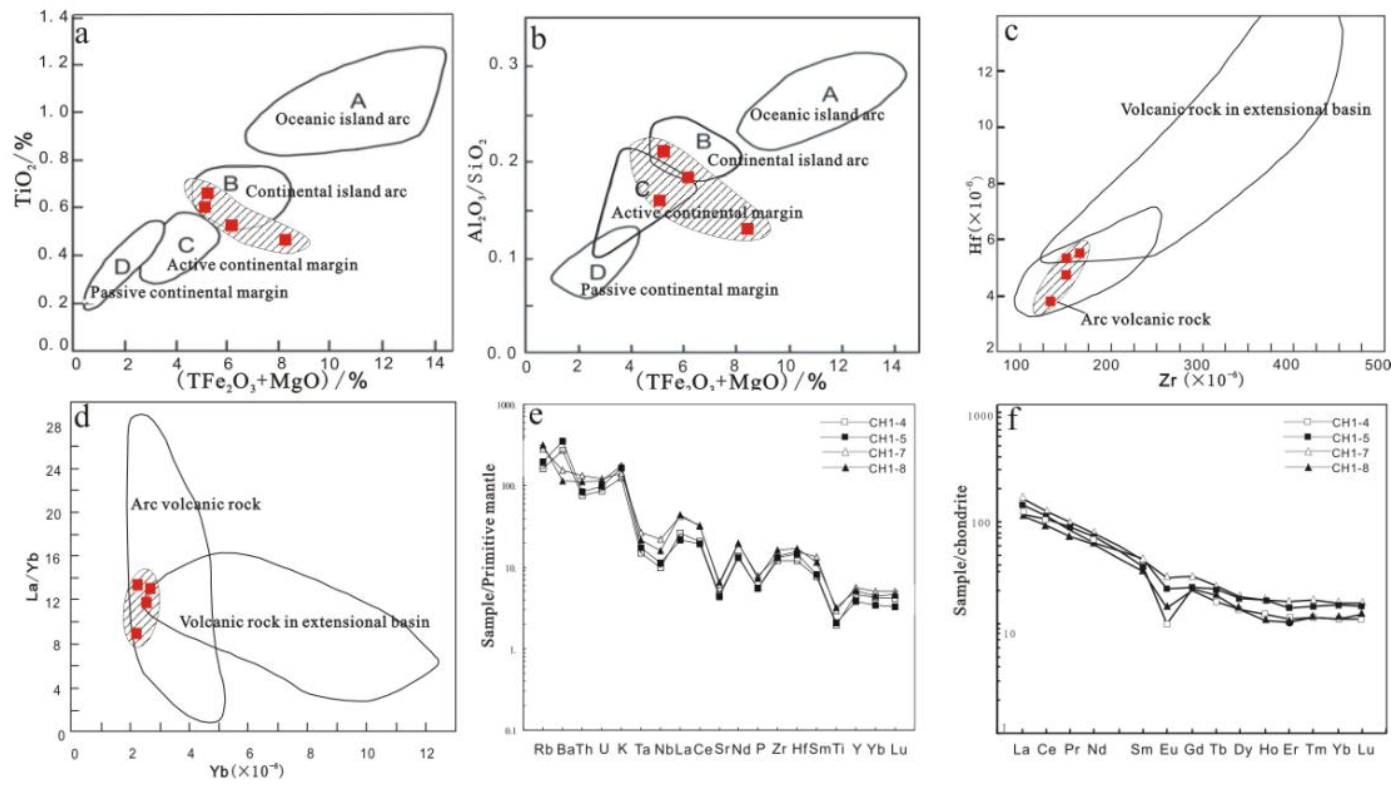

Figure 10. Diagram of rock geochemistry of ore-bearing wall rock; $a$ and b. $\mathrm{TiO}_{2}$ $\mathrm{TFe}_{2} \mathrm{O}_{3}+\mathrm{MgO}$ and $\mathrm{Al}_{2} \mathrm{O}_{3} / \mathrm{SiO}_{2}-\mathrm{TFe}_{2} \mathrm{O}_{3}+\mathrm{MgO}$ diagram of sedimentary protolith sample (Bhatia, 1991); $c$ and $d$. Hf-Zr and La/Yb-Yb diagram of igneous protolith sample (Condie, 1986); e. Chondrite-normalized REE patterns of igneous protolith sample; $f$. Primitive mantle-normalized spider diagrams of igneous protolith sample

The metallogenic characteristics and setting of early lamellar ore bodies are close to that of Japanese Kuroko-type massive sulfide deposit (Ohmoto, 1996; An et al., 2003; Ding and Cui, 2013), which imply that they have the similar cause. While, later veined ores in deposit were filled in extension fault without deformation and metamorphism action, whose metallogenic setting was obviously different from the oceanic crust subduction setting in the Middle-Late Silurian where the lamellar metallogenic was formed at the early stage, and the metallogenic setting will be discussed in the following parts.

\section{Metallogenic material source}

\section{Sulfur source}

The test results of sulfur isotope shows that $\delta^{34} \mathrm{~S}$ value of lamellar ore sulfide does not conform to the order of $\delta^{34} \mathrm{~S}$ enrichment in hydrothermal sulfide under fractionation equilibrium condition, which represents that the sulfur isotope in early ore-bearing fluid 
did not achieve fractionation equilibrium. Lamellar ores were formed in active epicontinental sea basin environment (Shan et al., 2009; Zheng and Chen, 2000). Due to the multi-source mechanism of seawater sulfate reduced sulfur as well as possible mixing process of magmatic sulfur and reduced sulfur, the unequilibrium relation among sulfur isotopes of this kind of symbiotic sulfide is very common in seafloor massive sulfide deposit(An et al., 2003; Zeng et al., 2007; Xue et al, 2011). The statistical analysis of sulfur isotope of more than 100 massive sulfide deposits shows that the sulfur of VMS type deposit has certain correlation with that of seawater in the same period. That is to say, the $\delta_{34} \mathrm{~S}$ value of VMS type sulfide deposit is about $15 \%$ less than that of seawater sulfate (Sangster, 1983), and the sulfate of seawater in the same period is a possible sulfur source of these sulfide deposits (Zeng et al., 2007; Xiao and $\mathrm{Ni}, 2000$ ). In this test, the $\delta_{34} \mathrm{~S}$ value of lamellar ore sulfide was between 4.37 and $6.87 \%$. While, the $\delta_{34} \mathrm{~S}$ component range of marine sulfate in the late period of the Early Paleozoic Era was between 20\%o and 25\%o (Hoster, 1977; Rees et al., 1978), and the difference value in $15 \%$ $18 \%$ existed. Therefore, the components of early lamellar ore sulfide isotope were likely formed under the mixing of the source of sulfide isotopes with low values and reduction of seawater sulfate with high values in unequilibrium condition. Ohmoto (1983) pointed that reduced seawater sulfate and magmatic sulfur were two main sources of sulfur in VMS deposit, and magmatic sulfur could be directly derived from magmatic exhalation. Therefore, volcanic magmatic sulfur $\left(\delta^{34} S \approx 0\right)$, as the end member components with $\operatorname{low} \delta^{34} \mathrm{~S}$ values, was in consistent with metallogenic process and the data that $\delta_{34} \mathrm{~S}$ value of sulfide samples was between the $\delta_{34} \mathrm{~S}$ values of magmatic sulfur and seawater sulfide. The $\delta_{34} \mathrm{~S}$ value $(4.32-6.75 \%$ ) of lamellar ore sulfide was very close to the $\delta_{34} \mathrm{~S}$ value (5.2-7.2 \%) of "Kuroko-type" VMS deposit (Ohmoto, 1983, 1996), which also implied that the source of two sulfurs might have similar fractional mechanism.

Correspondingly, The variation range of $\delta^{34} \mathrm{~S}$ value in hydrothermal vein type sulfide was narrow, the distribution interval of $-4.37 \sim+3.35 \%$ was distributed in tower form with mean value of $+0.81 \%$. The characteristics above showed the characteristics of deep source magmatic sulfur (Jochen et al., 2002), which were different from the source of lamellar ore sulfide. The $\delta_{34} \mathrm{~S}$ value order of hydrothermal vein ore sulfide doesn't conform to the order in hydrothermal sulfide under fractionation equilibrium condition either (Shan et al., 2009), mainly manifested as the relatively low $\delta^{34} S$ value of pyrite. It should be caused by the multi-stage fractionation of sulfide during the multistage hydrothermal activities (Zhong et al., 2013; Long et al., 2015), conforming to existence of multi-stage quartz vein and calcite vein in the field.

\section{Ore-forming fluid source}

\section{Hydrogen oxygen isotopes evidence}

$\mathrm{O}, \mathrm{H}$ isotope composition of lamellar ore quartz and veined quartz are shown in Figure 11a. Two kinds of samples all have similar ${ }^{18} \mathrm{O}_{\mathrm{H} 2 \mathrm{O}}$ value (4.37-6.87), while D of lamellar quartz is larger than veined quartz. There are mainly two cognitions for the source of ore-forming fluids of massive sulfide deposits: seawater generates isotope exchange and forms the enriched ${ }^{18} \mathrm{O}$ fluid (Beaty and Taylor, 1982; Barriga and Kerrich, 1984), or generates mixture of magmatic water and sea water (Yang and Scott, 1996; Hou et al., 2001, 2003). The lamellar quartz sample points are near to left side of primary magmatic water range, and have the tendency of pointing at seawater 
hydrothermal solution. Obviously, single seawater source is difficult to have above characteristics, and it is believed that meteoric water could not participate in mineralization directly in the condition that mineralized field was buried deeply under the seawater, and kept away from terrestrial sources (Ohmoto, 1996). Therefore, it was thought that the mixture of magmatic water and corresponding period seawater was the fluid source mechanism in early stage. Accordingly, veined quartz sample points fell on the bottom left of primary magmatic water, which indicated that magmatic water should be one of the main fluid sources, While smaller $\delta \mathrm{D}_{\text {Smow }}$ value shows that fluid may include late atmospheric precipitation (Xiang et al., 2012).Veined mineralization in the late stage was formed into hydrothermal solution activity after magma period. Atmospheric precipitation cycled in the building with ore, and mixed with rising magma hydrothermal solution, which were the possible fluid source mechanism.

\section{Ore rare earth element evidence}

Because the difference of $\mathrm{REE}^{3+}$ ion radius and $\mathrm{Fe}^{2+}, \mathrm{Cu}^{2+}, \mathrm{Zn}^{2+}$ radius is large. Replacing cations in sphalerite or pyrite mineral lattice is difficult (1991). REE in the sulfide mainly exists in the fluid inclusion or lattice imperfection of minerals, thus REE composition characteristics of sulfide can directly reflect REE composition characteristics in the ore-forming fluid (Huston et al., 1995; Haas et al., 1995). Figure $11 b$ shows that $\sum$ REE of veined sulfide is relative high, and has negative Eu anomaly, while $\sum$ REE of lamellar sulfide is small, and the majority samples of lamellar sulfide have positive $\mathrm{Eu}$ anomaly (excepting for galena samples). Research shows that two causes may be attributed to the Eu anomaly generated by Ore. On one hand, rich Eu is inherited from ore-forming fluid when the ore is precipitated; on the other hand, $\mathrm{Eu}^{2+}$ is carried out by the subsequent effect of fluid after the ore is formed, because $\mathrm{Eu}^{2+}$ with larger ion radius and smaller charge number are more easy to be carried out by the fluid compared with the other trivalent REE ion (Ding et al., 2003). Therefore, the positive $\mathrm{Eu}$ anomaly in the lamellar ore is not resulted from the effect of later geological processes. Research shows that the significant Eu positive anomaly and the relative enrichment of LREE are an important symbol for the composition of rare earth element in the submarine hydrothermal fluid (Bhatia, 1991; Haas et al., 1995; Klinkhammer and Edmond, 1994). From the observation and research of the modern submarine hydrothermal systems conducted by Mills and Elderfiel (1995), it is shown that sulfide generated in hydrothermal solution are similar with composition of hydrothermal fluid. The characteristics of REE of lamellar sulfide ore in mining area are similar with those in the submarine hydrothermal fluid, but with lower Eu positive value (1.25-2.50). So, we believe that the ore forming fluid of early satge of Caihong deposite include submarine hydrothermal fluid, while magmatic fluid component is mixed, because magmatic fluid will cause $\delta E u$ value decreased in ore forming fluid (Ding et al., 2003). Furthermore, the galena sample in the lamellar sulfide has negative $\mathrm{Eu}$ anomaly. Generally, as the temperature decreases and oxygen fugacity changes, the weak Eu positive anomaly, no abnormalities or Eu negative anomaly may appear in the mineral when $\mathrm{Eu}^{2+}$ and $\mathrm{Eu}^{3+}$ accounts for a considerable proportion in the solution (Song, 2011). The weak negative Eu anomaly in the galena may indicated that it is formed in the late period of volcanic eruption, which conforms to fact that the generation of galena in polished sections of ores is posterior to other sulfide.

On the other hand, the LREE in late veined ore sulfide is relatively rich, and has the moderate Eu negative anomaly. The characteristics of REE are similar with Zhong bao 
rock mass in the north of ore district (Chen et al., 2013). The conformance to the characteristics of REE implies that the source of fluid in the late stage may come from Zhongbao granite body. This understanding is also in compliance with the analysis result of hydrogen and oxygen isotopes in the veined ores.
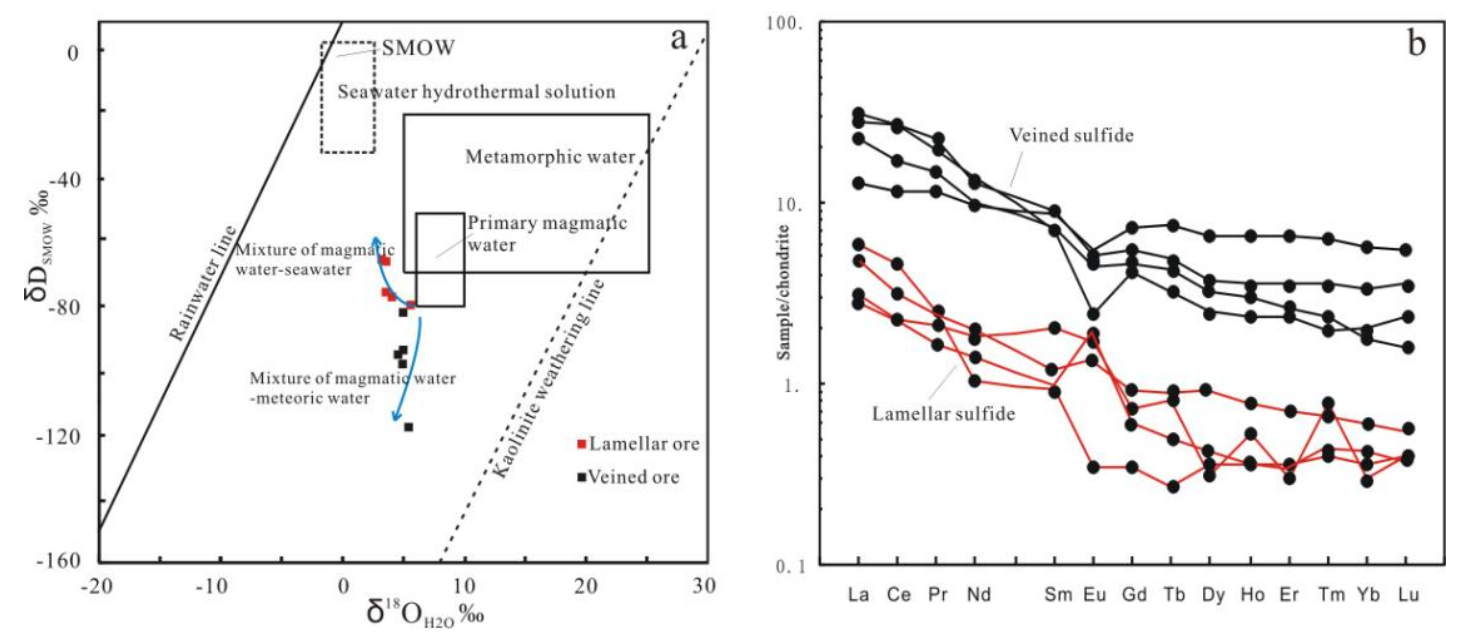

Figure 11. Hydrogen-oxygen isotopes dagram of ore quartz (a) and Chondrite-normalized REE patterns of ore sulfide $(b)$

\section{Discussion on genetic types of Caihong deposit}

The field characteristic and geochemical analysis on Caihong deposit clearly states that the deposit underwent two mineralization stages. The early ore-forming stage was formed in the plate subduction back-arc rift setting in the Middle-Late Silurian when the deposit was in bedded or quasi-bedded $\mathrm{Zn}-\mathrm{Pb}-\mathrm{Cu}$ ore bodies with syngenetic sedimentary characteristics. The bedded ore bodies are generated in the quartz-sericite lithified alteration zone of Aerbishimaibulake Formation subformation $\left(D_{1} a^{b}\right)$, while quartz-sericite lithification is generally considered to be the alteration product from the neutral-acid igneous rock encountering hydrothermal solution (Piercey et al., 2008). Therefore, ore bodies are actually produced in the dacite-rhyolitic pyroclastic rock. The above-mentioned characteristics of Caihong deposite are similar to the metallogenic features of kuroko-type VMS deposit (An et al., 2003; Piercey et al., 2008; Pan et al., 2015; Sun et al., 2011). Since no volcanic vent is found around the Caihong ore district and the original rock components of ore-bearing wall rock are pyroclastic rock and greywacke, it is predicted that Caihong deposit should be located in the depression at the edge of island arc and deviate from the center of volcano. The ore-forming materials carried by the gas-fluid from volcanic eruption form bedded sulfide ores in depression; while Caihuagou deposit in the eastern part of Caihong ore district have typical doublebed ore body structures with the upper bedded ore and the lower stockwork (San et al., 2009). The latest volcanic apparatus restoration in this area shows that Caihuagou deposit in the east of Caihong ore district is close to the eruptive vent, which indicate that the two deposits should be the products in different ore-forming positions, while in the same metallogenic system.

The late veined ore body is filled in the north-east trending brittle fault and has no deformation and metamorphism. Foregoing study shows that late ore-forming fluid is derived from the mix of magmatic water and atmospheric precipitation and sulfur is 
derived from magmatic sulfur. The source region that can supply the ore-forming materials shall be later than plate subduction and the deformation and metamorphism, and shall have proper distance and magmatic hydrothermal migration pathway. The regional stress shall take the tension stress as primary. Evidences suggest that Zhongbao granite body is formed in the collision-extension transformation stage of the plates in the Early Permian (Chen et al., 2013), which is later than the time of regional metamorphism and deformation (Wu et al., 1992). Moreover, Caihong ore district has obviously $\mathrm{W}$ geochemical anomaly, and has obviously north-east trending distribution with $\mathrm{Cu}, \mathrm{Pb}, \mathrm{Zn}$ elements (Xue et al., 2012), indicating that north-east trending fault in ore district could be the migration pathway of magmatic hydrothermal. In addition, the content characteristic of REE in veined ore sulfide is obviously similar with Zhongbao granite body. According to the above evidences, it can be concluded that the intrusion of Zhongbao granite body and subsequent hydrothermal activity in Early Permian is the main cause of forming late veined ore body, which provide the source of ore-forming sulfur and main fluid. The hydrothermal solution migrates along the late NE trending extension fault and activates ore-forming elements in host rock, forming the veined $\mathrm{Cu}$, $\mathrm{Pb}, \mathrm{Zn}$ ore body in fault development part. As the main structure activities in this stage region has been finished, the late veined ore body has been kept better and no deformation and metamorphism.

\section{Conclusions}

The following conclusions are obtained through above discussion:

1. The genetic type of Caihong $\mathrm{Cu}, \mathrm{Pb}, \mathrm{Zn}$ polymetallic deposit is volcanic exhalation sedimentary- magmatic hydrothermal superimposed type.

2. The first metallogenic stage is formed in the oceanic crust subduction island-arc rift setting in the Middle-Late Silurian. Metallogenic sulfur is derived from the mixing of continental marginal arc volcanic magmatic sulfur and sulfur reduced by seawater sulfate in the same period, and ore-forming fluid is derived from the mixing of submarine hydrothermal solution and volcanic magmatic water.

3. The second metallogenic stage is formed by the invasion of Zhongbao granitic body and late magmatic hydrothermal action in the collision-extension transformation stage of the plates in Early Permian. Metallogenic sulfur is derived from magmatic sulfur of Zhongbao granite, and ore-forming fluid is derived from the mixing of deep magmatic water and atmospheric precipitation. The genetic type of this stage is the hydrothermal filling metasomatic type after magma stage.

Acknowledgements. This study was financially supported by the project of Metallogical condition research and ore prospecting target area evalution of copper-gold-iron metallogenic belt in Kuruktag (2011BAB06B04) .We appreciate the engineers of Caihong deposite for their help and fruitful discussion during our field investigations.

\section{REFERENCES}

[1] An, W., Cao, Z.M., Zheng, J.B., Liu, J., and Chen, M. (2003): The development of study on ancient and modern volcanogenic massive sulfide deposite. -Advance in Earth Science 18: 773-782. (in Chinese with English abstract)

[2] Barriga, F.J., and Kerrich, R. (1984): Extreme ${ }^{18} \mathrm{O}$-enriched volcanics and ${ }^{18} \mathrm{O}$-evolved 
marine water, Aljustrel, Iberian pyrite belt: transition from high to low Rayleigh number convective regimes. -Geochimica et Cosmochimica Acta 48: 1021-1031.

[3] Bau, M. (1991): Rare earth element mobility during hydrothermal and metamorphic fluidrock interaction and the significance of the oxidation state of europium. -Chemical Geology 93: 219-230.

[4] Beaty, D.W., and Taylor, H.P. (1982): Some petrologic and oxygen isotopic relationships in the Amuletmine, Noranda, Quebec, and their bearing on the origin of Archean massive sulfide deposits. -Economic Geology 77: 95-108.

[5] Bhatia, M.R. (1991): Plate tectonics and geochemical composition of sandstones. Journal of Geology 6: 611-629.

[6] Cavosie, A. J., Valley, J. W., Wilde, S. (2006): Correlated micro-analysis of zircon: Trace element, $\mathrm{d}^{18} \mathrm{O}$, and $\mathrm{U}-\mathrm{Th}-\mathrm{Pb}$ isotopic constraints on the igneous origin of complex $>3900$ Ma detrital grains. -Geochimica et Cosmochimica Acta 70: 5601-5616.

[7] Chen, C., Lü, X.B., Cao, X.F., Wu, C.M., and Zhu, J. (2013): Geochronology, geochemistry and geological significance of late Carboniferous-early Permian granites in Kumishi area, Xinjiang. -Earth Science-Journal of China University of Geosciences 38: 218-232. (in Chinese with English abstract)

[8] Chen, C., Lü, X.B., Wu, C.M., Li, P., Cao, X.F., and Zhu, J. (2013): Geological characteristics and genesis of the Zhongbao tungsten deposit in Kumishi area, Xinjiang, China. -Bulletin of Mineralogy, Petrology and Geochemistry 32: 445-455. (in Chinese with English abstract)

[9] Condie, K.C. (1986): Plate tectonics and crustal evolution. -Wuhan College of Geology, Wuhan.

[10] Crook, A.W. (1974): Lithogenesis and geotectonics: the significance of compositions in flysch arenites (graywackes). -In: Dott, R.H., and Shaver, R.H., Modern and Ancient Geosynclinal Sedimentation. Tulsa: SEPM Special Publication 19: 304-310.

[11] Ding, S.X., and Cui, J.Q. (2013): Research progress on volcanogenic massive sulfide deposit. -Geology and Resources 22: 243-249. (in Chinese with English abstract)

[12] Ding, Z.J., Yao, S.Z., Liu, C.Q., Zhou, Z.G., and Yang, M.G. (2003): The characteristics of exhalation-sedimentary deposit of Donggouba polymetal deposit: evidence from ore' $s$ REE composition. -Acta Petrologica Sinica 19: 792-798. (in Chinese with English abstract)

[13] Dong, Y.P., Zhou, D.W., Zhang, G.W., Zhang, C.L., Xia, L.Q., Xu, X.Y., and Li, X.M. (2005): Tectonic setting of the Wuwamen ophiolite at the southern margin of Middle Tianshan belt. -Acta Petrologica Sinica 21: 37-44. (in Chinese with English abstract)

[14] Haas, J.R., Shock, E.L., and Sassani, D.C. (1995): Rare earth elements in hydrothermal systems: Estimates of standard partial modal thermodynamic properties of aqueous complexes of the rare earth elements at high pressures and temperatures. -Geochimica Cosmochimica Acta 59: 4329-4350.

[15] Holser, W.T. (1977): Catastrophic chemical events in the history of the ocean. -Nature, 267: 403-408.

[16] Hou, Z.Q., Khin, Z., Qu, X.M., Ye, Q.T., Yu, J.J., Xu, M.J., Fu, D.M., and Yin, X.K. (2001): Origin of the Gacun volcanic-hosted massive sulfide deposit in Sichuan, China: Fluid inclusion and oxygen isotope evidence. -Econonic Geology 96: 1491-1512.

[17] Hou, Z.Q., Li, Y.Q., Zhang, Q.L., and Qu, X.M. (2003): End-members and mixing of fluids in submarine hydrothermal system: evidence from fluid inclusions in the Baiyinchang and Gacun VMS deposits. -Acta Petrologica Sinica 19: 221-234. (in Chinese with English abstract)

[18] Hu, A.Q., Zhang, G.X., and Chen, Y.B. (2006): Geochronology and geochemistry study of the main geological events of the crustal evolution in Xinjiang, China. -Geological Publishing House, Beijing. (in Chinese)

[19] Huston, D.L., Sie, S.H., and Suter, C.F. (1995): Trace elements in sulfide minerals from eastern Australian volcanic-hosted massive sulfide deposit. -Economic Geology 90: 
1167-1196.

[20] Jiang, C.Y., Wu, W.K., Yang, F., Mo, S.L., and Li, L.C. (1993): Tectonic movement during late Caledonian in Tianshan mountain and its geological significance. -Journal of Xi'an College of Geology 15: 41-46. (in Chinese with English abstract)

[21] Jochen, H., Liu, S.F., and Shi, X.F. (2002): Stable isotope geochemistry. -Ocean Press, Beijing.

[22] Klinkhammer, G.P., and Edmond, J.M. (1994): Geochemical implications of rare earth element patterns in hydrothermal fluid from mid-ocean ridges. -Geochimica et Cosmochimica Acta 58: 5105-5113.

[23] Liu, Y.S., Hu, Z.C., Gao, S., Günther, D., Xu, J., Gao, C.G., and Chen, H.H.(2008): In situ analysis of major and trace elements of anhydrous minerals by LA-ICP-MS without applying an internalstandard. -Chemical Geology 257: 34-43.

[24] Liu, Y.S., Hu, Z.C., Zong, K.Q., Gao, C.G., Gao, S., Xu, J. and Chen, H.H. (2010): Reappraisement and refinement of zircon $\mathrm{U}-\mathrm{Pb}$ isotope and trace element analyses by LA-ICP-MS. -Chinese Science Bulletin 55: 1535-1546.

[25] Long, L.L., Gao, J., Xiong, X.M., and Qian, Q. (2007): Geochemistry and geochronology of granitoids in Bilcai region, southern Central-Tianshan mountains, Xinjiang. -Acta Petrologica Sinica 23: 71-73. (in Chinese with English abstract)

[26] Long, L.L., Wang, J.B., Wang, Y.W., Wang, L.J., Liao, Z., Zhao, L.T., Sun, Z.Y., and Gao, L.M. (2015): Sulfur-isotope characteristics and discussion on the source of oreforming material of the Xilekuduke $\mathrm{Cu}-\mathrm{Mo}$ deposit, Xinjiang Province. -Acta Petrologica Sinica 31: 545-554. (in Chinese with English abstract)

[27] Mills, R., Elderfield, H. (1995): Rare earth element geochemistry of hydrothermal deposits from the active TAG Mount, $26^{\circ} \mathrm{N}$ mid-Atlantic Ridge. -Geochim. Cosmochim. Acta 59: 3511-3524.

[28] Ohmoto, H. (1983): Geologic setting of the Kuroko deposits, Japan: Part I, geologic history of the Green Tuff Region. -Econonic Geology 5: 9-23.

[29] Ohmoto, H. (1996): Formation of volcanic-associated massive sulfide deposits: The Kuroko perspective. -Ore Geology Review 10: 135-177.

[30] Pan, M.H., Jia, Z.L., Ou, J., and Hou, P.B. (2015): Geochemical characteristics of sericitolite in Huashigou copper deposit, South Qilian, Gansu. -Geochimica 44: 370-376. (in Chinese with English abstract)

[31] Peng, Y.M., Pan, G.T., and Luo, J.N. (1999): Volcanic-sedimentary characteristics of back-arc basin. -Sedimentary Fades and Palaeogeography 19: 65-72. (in Chinese with English abstract)

[32] Piercey, S.J., Peter, J.M., and Mortensen, J.K. (2008): A special issue devoted to continental margin massive sulfide deposites and their geodynamic environments. Economic Geology 103: 1-10.

[33] Rees, C.E., Jenkins, W.J., and Monster, J. (1978): The sulfer isotopic composition of ocean water sulfate. -Geochimica et Cosmochimica Acta 42: 377-381.

[34] San, X.L., Xu, S., and Zheng, Y.Z. (2009): Prospecting model of Caihuagou cupriferous copperprite deposite in Xinjiang. -XinJiang Geology 27: 32-37. (in Chinese with English abstract)

[35] Sangster, D.F. (1983): Shourt course in sediment-hosted stratiform lead-zinc deposits. Mineralogical Association of Canada 8: 6-26.

[36] Shan, L., Zheng, Y.Y., Xu, R.K., Cao,L., Zhang,Y.L., Lian,Y.L., and Li, Y.H. (2009): Review on sulfur isotopic tracing and hydrothermal metallogenesis. -Geology and Resource 18: 188-203. (in Chinese with English abstract)

[37] Shu, L.S., Lu, F.H., Yin, D.H., and Wang, B. (2003): Paleozoic accretion-collision events and kinematics of ductile deformation in the Central-Southern Tianshan belt. -Journal of Nanjing University(Nature Science) 39: 17-30. (in Chinese with English abstract)

[38] Simonen, A. (1953): Stratigraphy and sedimentation of the Svecofennidic, early Archean 
supracrusatal rocks in southwestern Finland. -Bulletin of the Geological Society of Finland 160: 1-64.

[39] Song, S.M (2011): Multi-isotopic and REE geochemistry on tracing formation of the Dajiangping and Dabaoshan sulfide ore deposits in Guangdong province, south China. Ph.D. Thesis, Nanjing University, Nanjing. (in Chinese with English abstract)

[40] Su, Y.Y., Lü, X.B., Gao, B.M., Ma, Y.L., Chen, C., Li, P. (2011): Geological characteristics and genesis of Cai hong $\mathrm{Cu}$-polymetalic deposit in Xinjiang. -Mineral Deposites 30: 139-148. (in Chinese with English abstract)

[41] Sun, H.S., Wu, G.B., Liu.L., Xie, X.F., and Duan, L. (2011): Research advances in metallogenic tectonic environment of massive sulfide deposits. -Earth Science-Journal of China University of Geoscience 36: 299-306. (in Chinese with English abstract)

[42] Tarney, J. (1976): Geochemistry of Archean high grade gneiss, with implications as to origin and evolution of the Precambrian crust. -In: Windley, B.F. (Ed.) The early history of Earth. London(Wiley).

[43] Wang, R.M., He, G.P., and Chen, Z.Z (1987): Graphic discrimination method of metamorphic rocks. -Geological Publishing House, Beijing. (in Chinese)

[44] Whitehouse, M.J. (2003): Rare earth elements in zircon: a review of applications and case studies from the outer Hebridean Lewisian Complex, NW Scotland. -In: Vance, D., Muller, W., and Villa, I.M. Geochronology: linking the isotopic record with petrology and textures 220, Geological Society, London, Special Publications.

[45] Winchester, J.A., and Floyd, P.A. (1977): Geochemical discrimination of different magma series and their differention products using immobile elements. -Chemical Geology 20: 325-343.

[46] Wu, W.K., Jiang, C.Y., and Yang, F. (1992): Paleozoic crustal evolution and metallogenic regularity of Kumux area. -Science and Technology Publishing House, ShanXi. (in Chinese)

[47] Xiang, J.F., Pei, R.F., Ye, H.S., Wang, C.Y., and Tian, Z.H. (2012): Source and evolution of the ore-forming fluid in the Nannihu-Sandaozhuang Mo (W) deposit: Constraints from C-H-O stable isotope data. -Geology in China: 1778-1789 (in Chinese with English abstract)

[48] Xiao, J.X., and Ni, P. (2000): Discussion of comparison of metallogeny for SEDEX and Sedimentary-rework basemetal deposits. -Contributions to Geology and Mineral Resources Research 15: 238-245. (in Chinese with English abstract)

[49] Xue, J., Dai, T.G., Fu, S.W., Ma, G.Q., and Huang, W.M. (2011): SEDEX origin of the Panlong lead-zinc deposit, Wuxuan, Guangxi: REE and $\mathrm{S}$ isotope evidences, Geotectonica et Metallogenia 35: 394-403. (in Chinese with English abstract)

[50] Xue, J.C., Tian, Z.F., Guo, Y. (2012): Geological characteristics and genesis of Caihong $\mathrm{Cu}$-polymetalic deposit in Tuokexun, Xinjiang. -West-China Exploration Engineering 12: 104-113. (in Chinese with English abstract)

[51] Yang, K.H., and Scott, S.D. (1996): Possible contribution of metal-rich magmatic fluid to a seafloor hydrothermal system. -Nature 383: 420-423.

[52] Yang, T.N., and Wang, X.P. (2006): Geochronology, petrochemistry and tectonic implications of Early Devonian plutons in Kumux area, Xinjiang. -Acta Petrologica Mineralogical 225: 401-411. (in Chinese with English abstract)

[53] Yang, T.N., Li, J.Y., Sun, G.H., and Wang, Y.B. (2006): Earlier Devonian active continental arc in Central Tianshan: evidence of geochemical analyses and zircon SHRIMP dating on mylonitized granitic rock. -Acta Petrologica Sinica 22: 41-48. (in Chinese with English abstract)

[54] Zeng, Q.D., Liu, J.M., and Jia, C.S. (2007): Sedimentary exhalative origin of the Baiyinnuoer zinc-lead deposit, Chifeng, inner Mongolia: geological and sulfur isotope evidence. -Journal of Jilin University(Earth science edition) 37: 659-667. (in Chinese with English abstract)

[55] Zhang, C.L., Zhou, D.W., Wang, J.L., and Wang, R.S. (2007): Geochronology, 
geochemistry and $\mathrm{Sr}-\mathrm{Nd}$ isotopic composition and genesis implications of Huangjianshishan granite intrusion in Kumishi area of southern Tianshan. -Acta Petrologica Sinica 23: 1821-1829. (in Chinese with English abstract)

[56] Zhang, L.G., Liu, J.X., Zhou, B., and Chen, Z.S (1990): A pestudy on oxygen isotope equiliberation between quartz and water system:salt isotope effect and others. -Bulletin of the Chinese Academi of Geological Sciences 20: 6-62. (in Chinese with English abstract)

[57] Zhang, X.P., Wang, Q.F., and H, J. (2015): Chemical characteristics of volcanic rocks from the Tanjianshan group on the northern margin of the qaidam basin and its tectonic environment. -Mineral Petrol 35: 18-26. (in Chinese with English abstract)

[58] Zheng, Y.F., and Chen, J.F. (2000): Stable isotope geochemistry. -Science Press, Beijing. (in Chinese )

[59] Zhong, K.H., Liao, W.,Song, M.Y., and Zhang, Y.Q. (2013): Discussion on sulfur isotope of Huize Pb-Zn deposite in Yunnan, China. -Journal of Chendu University if Technology (Science\&Technology Edition) 40: 130-138. (in Chinese with English abstract)

[60] Zhu, Z.X., Wang, K.Z., Zheng, Y.J., Sun, G.H., Zhang, C., and Li, Y.P. (2006): Zircon SHRIMP dating of Silurian and Devonian granitic intrusions in the southern Yili block, Xinjiang and preliminary discussion on their tectonic setting. - Acta Petrologica Sinica 22: 1193-1200. (in Chinese with English abstract) 